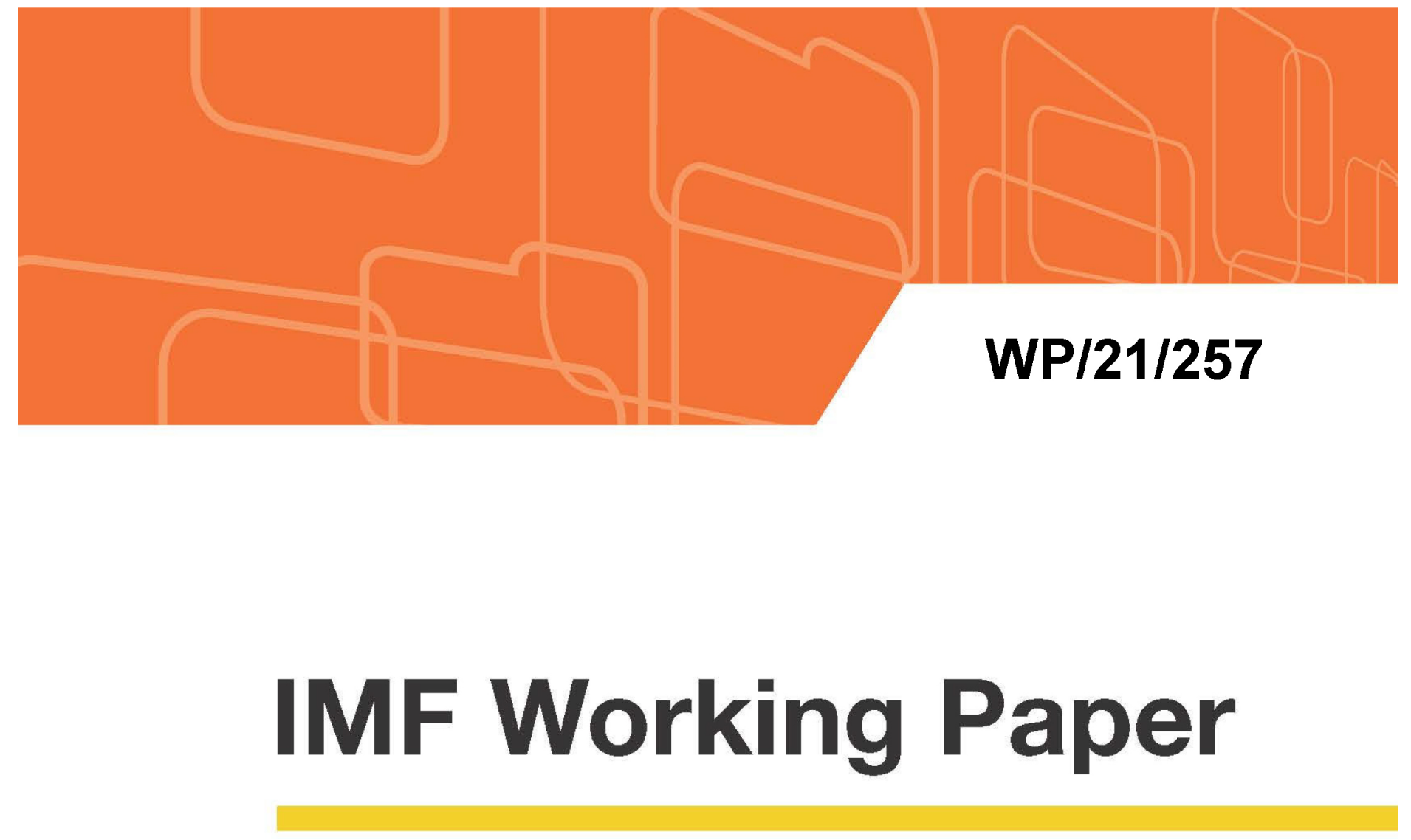

\title{
Household Deleveraging and Saving Rates: A Cross-Country Analysis
}

\author{
by Romain Bouis
}

IMF Working Papers describe research in progress by the author and are published to elicit comments and to encourage debate. The views expressed in IMF Working Papers are those of the author and do not necessarily represent the views of the IMF, its Executive Board, or IMF management. 


\title{
IMF Working Paper
}

Monetary and Capital Markets Department

\section{Household Deleveraging and Saving Rates: A Cross-Country Analysis \\ Prepared by Romain Bouis*}

Authorized for distribution by Montfort Mlachila

October 2021

\section{IMF Working Papers describe research in progress by the author and are published to elicit comments and to encourage debate. The views expressed in IMF Working Papers are those of the author and do not necessarily represent the views of the IMF, its Executive Board, or IMF management.}

\begin{abstract}
Historically high household debt in several economies is calling for a deleveraging, but according to some economists, this adjustment can slow GDP growth by weighing on consumption. Using a sample of advanced and emerging market economies, this paper finds evidence of a negative relationship between changes of household debt-to-income ratios and saving rates. This relationship is however asymmetric, being significant only for debt build-ups. Declining debt ratios and saving are significantly related in some economies, but the relationship is driven by consumer credit, not by mortgages. Results therefore suggest that the economic cost associated with household deleveraging may be overestimated and motivate a deleveraging via lower mortgages.

JEL Classification Numbers: G01; E21; E44.

Keywords: Household debt; saving rates; consumption growth; deleveraging; consumer credit; mortgages; housing equity withdrawal.

Author's E-Mail Address: rbouis@imf.org

\footnotetext{
* I would like to thank participants at internal seminars at Banque de France, BIS, IMF, OECD, to the CEMLA in Mexico City, at the $3^{\text {rd }}$ UECE conference in Lisbon, and at the KDI International Conference "Household Debt from an International Perspective: Issues and Policy Directions" in Seoul, as well as Luis Brandao-Marques, Daniel Cooper, Ulric Eriksson von Allmen, Marco Gross, Aiko Mineshima, Montfort Mlachila, Lars Svensson, and Christian Upper for useful comments and suggestions on an earlier version of the paper. Many thanks to Anne-Katherine Christensen and Seung-Hee Koh from the OECD for data support. The usual disclaimer applies.
} 
ABSTRACT

I. INTRODUCTION

II. DEFINITION OF HOUSEHOLD DELEVERAGING

III. THE RELATIONSHIP BETWEEN CREDIT AND SAVING

A. Why Deleveraging and Saving Rates are Empirically Positively Correlated

B. Implications in Terms of Cross-Country Heterogeneity $\underline{16}$

IV. EMPIRICAL APPROACH $\underline{17}$

V. ESTIMATION RESULTS

A. Baseline Regressions $\frac{21}{26}$

B. Cross-Country Heterogeneity and the Role of Credit Market Institutions $\underline{26}$

C. Consumer versus Mortgage Debt Ratios $\underline{30}$

VI. CONCLUSION $\underline{34}$

REFERENCES $\underline{45}$

Figures

1 - Changes in average saving rates from credit booms to deleveraging periods

2 - Changes of macroeconomic variables around historical debt turning points

3 - Net credit-to-disposable income ratios and saving rates

4 - Contributions of changes of consumer and of mortgage debt ratios

\section{Tables}

1 - Changes in household debt ratios and saving rates during full boom-bust credit cycles

2 - Changes of household debt ratios and saving rates in selected ongoing deleveraging economies 10

3 - Differences in credit market features, homeownership rates, and pension funds

4 - Saving rate and change in debt ratios, baseline

5 - Saving rate and interaction effects of institutional settings with change of debt ratios

6 - Saving rate, consumer credit, and mortgages

\section{Appendix Tables}

1 - Variable definitions and data sources $\underline{37}$

2 - Change in saving rate and positive versus negative changes of debt ratios

3 -Consumption growth and positive versus negative changes of debt ratios

4 - Change of saving rate and interaction effects of institutional settings

5 - Consumption growth and interaction effects of institutional settings with change of debt ratios

6 - Change of saving rate, consumer credit, and mortgages $\underline{28}$

7 - Consumption growth, consumer credit, and mortgages

$\frac{\frac{39}{40}}{\frac{41}{42}}$




\section{INTRODUCTION}

Following a sharp increase in the run-up to the Global Financial Crisis (GFC), household debt-to-disposable income ratios have declined in some countries (e.g., Denmark, Greece, Hungary, Ireland, the Netherlands, Portugal, Spain, United Kingdom, United States, etc.) but have kept increasing in others (e.g., Australia, Belgium, Canada, Finland, France, Korea, Norway, Sweden, Switzerland, etc.), reaching historical highs on the back of ultraaccommodative financing conditions (Appendix Figure 1). The coronavirus (COVID-19) crisis has further highlighted vulnerabilities of indebted households to financial and income shocks (Zabai, 2020), reminding that deleveraging remains topical on the macro-prudential policy agenda.

According to the current consensus, household deleveraging would, however, put a drag on economic growth as declining debt ratios are historically accompanied by higher household saving rates (Figure 1). In the United States, where debt-to-income ratios have declined by more than 30 percentage points since end-2007, household deleveraging has been considered as responsible for the spectacular drop in consumption growth in the wake of the GFC (Glick and Lansing, 2011 or Dynan, 2012). ${ }^{1}$ Several analyses have therefore warned of potential macroeconomic costs associated with the household deleveraging that may take place in other countries (e.g., Cuerpo et al., 2013 for European economies; Krugman, 2013 for Canada; Morgan Stanley, 2019 for Australia, Canada, and Sweden).

Figure 1 - Changes in average saving rates from credit booms to deleveraging periods (percentage points of disposable income)

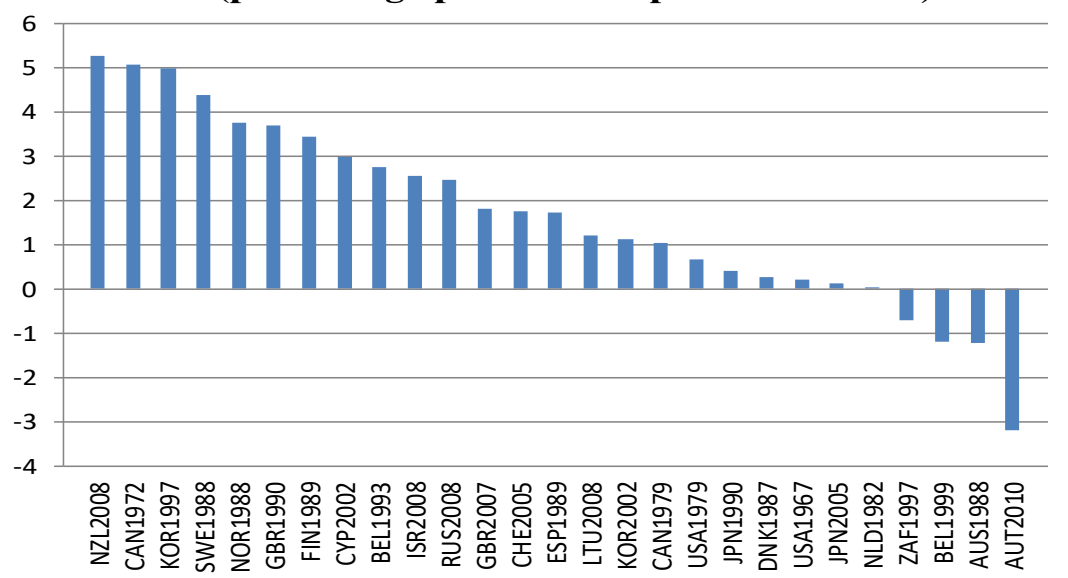

Sources: OECD, BIS, national accounts, and author's calculations.

Note: Years refer to the peak of the household debt-to-disposable income ratio. Average saving rates are computed over 5 years before the drop of the debt ratio (peak year included) for the boom phase, and from the peak to the trough of the debt ratio (peak year excluded) for the deleveraging phase. The change in the average saving rate is the difference between the average saving rate computed over the deleveraging period and the average saving rate computed over the boom period. In the case of Korea 2002, the Netherlands 1982, and South Africa 1997 episodes, the boom phase is defined over the two years preceding the peak (to avoid an overlap with the previous deleveraging episode in the case of Korea, and due to data availability in the two other cases).

\footnotetext{
${ }^{1}$ Theoretical literature (e.g., Eggertson and Krugman, 2012; Guerrieri and Lorenzoni, 2017; and Hall, 2011; Korinek and Simsek, 2016) also points to significant negative effects of household deleveraging on private consumption and output. Guerrieri and Lorenzoni (2017) estimate for instance that a decline in the household debt-to-GDP ratio by 10 percentage points generates a 1-percent drop in output.
} 
The relationship between saving and deleveraging is, however, not clear-cut on theoretical grounds. Two arguments are generally put forward by economists to justify a dampening effect of deleveraging on consumption. First, by increasing debt repayments to reduce their indebtedness, households prioritize saving over consumption (Dombret, 2013; Glick and Lansing, 2011; McCarthy and McQuinn, 2017; Mian and Sufi, 2014). Second, by cutting new borrowings normally used to finance consumption, households reduce spending. ${ }^{2}$ Some theoretical models (Eggertson and Krugman, 2012; Korinek and Simsek, 2016) also claim that the debt reduction of highly indebted agents who are forced to deleverage (the "borrowers") translates into a drop of aggregate consumption if the consumption of other agents (the "lenders") does not increase enough to compensate. ${ }^{3}$

In practice, however, the bulk of the reduction in household debt is not driven by higher debt repayments, but by lower new borrowings (in absolute terms, or in relation to income growth) and by rising debt defaults (Bhutta, 2015). Expanding debt defaults tend to support consumption, acting as a "financial decelerator" (Elul, 2008), while the macroeconomic impact of lower new borrowings on consumption depends on the importance of consumer credit in the economy whereas the bulk of household debt is made of mortgages. In this context, there is no automatic link between household deleveraging and saving and the rise of saving rates usually observed during deleveraging episodes may essentially reflect higher precautionary saving in an environment of heightened economic uncertainty, higher unemployment, and depressed valuations of real and financial assets, without any direct connection to changes in household debt.

Against this backdrop, this paper examines the relationship between household saving rates and the change of debt ratios for a sample of 39 countries over the period 1980-2019 to shed light on the macroeconomic costs of household deleveraging. Several studies have already examined the role of credit in explaining household saving rates. This paper differs from previous literature in two respects. First, it uses household debt series compiled for a large sample of countries from national balance sheet statistics (see Bouis et al., 2013 for details). Other panel studies use instead a broader measure of total credit to the non-financial sector, that is including households and private non-financial companies (e.g., Lyoza et al., 2000 or Mody et al., 2012).

Second, while existing literature focuses on the negative effect of credit on saving stemming from credit market liberalization, the change in credit conditions considered in this paper is

\footnotetext{
${ }^{2}$ The U.K. Office for National Statistics (2017) notes for instance that in the context of the GFC "the deterioration in labour market conditions and the outlook for household finances led to a process of household deleveraging, in which households reduced their liabilities relative to income, by paying down debt or cutting down on new borrowing. This led to consumers cutting back on spending." Likewise, Morgan Stanley (2019) argues that " (...) although GDP and consumption growth is boosted while households are gearing up, this process tends to go into reverse when the necessary deleveraging takes place. Paying down debt leads to belowtrend consumer spending which feeds into slower economic growth."

${ }^{3}$ This can happen in situations where lenders have a lower marginal propensity to consume than borrowers or because the interest rate does not drop enough to induce the needed increase of spending, due to the zero lower bound constraint.
} 
decomposed into rising and declining debt ratios. By looking specifically at the effects of debt ratio declines on saving for a sub-sample of observations covering historical and ongoing boom and bust credit cycles, this paper provides the first cross-country estimates of the relationship between credit and saving during deleveraging episodes.

The empirical analysis yields two main results. First, the negative relationship between changes in debt ratios and saving rates is statistically significant only for rising indebtedness in the average economy. Even when limiting the estimation sample to observations focusing on boom-bust credit cycles, the effect on saving rates or on consumption growth of declining debt ratios is insignificant. ${ }^{4}$ The asymmetric impact of credit on saving may reflect a financial-deepening effect of credit market liberalization, while financial reform reversals are scarce and business-cycle changes of saving rates are weakly related to changes of debt ratios in the average economy.

Second, panel estimates of the saving-credit relationship hide substantial cross-country heterogeneity, reflecting in part differences in the importance of consumer credit. Declining household debt ratios do not impact saving or consumption growth in economies with poorly-developed consumer credit markets but do translate into higher saving rates or lower consumption growth in economies where consumer credit is prevalent (e.g., in Australia, Canada, Korea, the United Kingdom, and the United States). Estimates of the separate impacts of consumer credit and of mortgages show that the decline in consumer debt ratios is significantly related to saving ratios while the decline in mortgage debt ratios (which, however, represents the bulk of household debt) is not, further highlighting the role of consumer credit in driving the deleveraging-saving relationship.

This result could reflect a reverse causality issue between consumer credit and saving. Empirical evidence for the United States, however, suggests that the contraction in consumer credit observed in the early phase of the GFC was mainly due to some cutbacks in the provision of credit by banks (Gropp et al., 2019), rather than to reduced credit demand from households stemming from standard wealth effects. ${ }^{5}$ With consumption of liquidityconstrained households being affected by this credit tightening, the macroeconomic impact of deleveraging crucially depends on the size of the consumer credit market in the economy.

Empirical analysis therefore suggests that the costs associated with household deleveraging driven by lower new mortgages (which represent the bulk of deleveraging) may be overestimated. The effect of changes in debt ratios on saving is asymmetric for the average

\footnotetext{
${ }^{4}$ The deleveraging literature focuses on the impact of the change in debt ratios on saving rates, consumption growth, or the two simultaneously. Although "household consumption growth" and "household saving rates" are used interchangeably throughout this paper, these two variables are of course different, and their analysis can be considered as complementary.

${ }^{5}$ As noted by Gropp et al. (2019), new consumer borrowing in the United States may have declined with the housing bust as households optimally reduced their demand for debt and implicitly, for consumption, in response to a negative shock on wealth (demand-side explanation). Alternatively, banks may have tightened their credit standards in areas where real estate prices declined more sharply (supply-side explanation). Evidence tends to support the supply-side explanation.
} 
economy, in line with the conclusion reached by Carroll et al. (2019) for the United States that increased credit availability accounts for most of the trend decline in saving, while fluctuations in wealth and uncertainty capture the bulk of the business-cycle variation. ${ }^{6}$ They also lend support to findings by Takáts and Upper $(2012,2013)$ that the strength of the economic recovery is poorly correlated with private debt deleveraging.

The cushioning effect of defaults on the decline of consumption may in theory explain the weak impact of deleveraging on saving. While rising debt is associated with higher spending, defaults accompanying deleveraging could mitigate the fall in consumption resulting from lower credit growth as households' cessation of debt repayments raises the amount of income available for consumption. Given the lack of debtor-friendly arrangements for households in most countries, the asymmetric debt impact documented here is, however, unlikely to be explained by the "financial decelerator" effect of defaults.

Another explanation may lie in the relatively modest response of consumption to short-term credit developments in some countries. In particular, in economies with poorly developed consumer credit markets and where rising debt ratios had therefore limited effects on consumption over the past twenty years, there may be no reason to expect any large effect of deleveraging on saving rates. Deleveraging in these countries may be merely associated with lower housing prices, without any significant impact on saving given the controversial effect of housing wealth on consumption (e.g., Cooper and Dynan, 2016 for a survey on wealth effects on household consumption).

This paper complements the large literature on the impact of the level of household debt on consumption and growth (the debt overhang effect) by looking at the macroeconomic cost of the impact of the decrease of the household debt ratio on the saving rate and consumption growth (the deleveraging effect). Several papers already document that household debt negatively affects consumption and GDP growth. Mian and Sufi (2011a) find that high household debt built up in some U.S. counties during the boom led to weaker economic conditions in those counties in the early part of the recovery. Mian et al. (2013) estimate a larger response of consumption to negative shocks to household wealth for households with higher leverage and for those who are more likely to be in negative equity, a result whose robustness has however been challenged recently by Kaplan et al. (2020). Dynan (2012) and Dynan and Edelberg (2013) find that excessive leverage has contributed to the weakness in consumption in the wake of the crisis. ${ }^{7}$ Baker (2018) shows that highly indebted households cut consumption significantly more in response to negative income shocks relative to households with relatively little debt.

\footnotetext{
${ }^{6}$ The authors find that the largest contributor to the decline in consumption in the U.S. during the GFC was the collapse in household wealth, followed by the increase in precautionary saving while credit availability played a substantially smaller role.

${ }^{7}$ Dynan (2012) however recognizes that the economic impact of leverage is relatively modest while the econometric estimates have large standard errors. An increase in the household's mortgage leverage ratio of 0.1 is for instance associated with a decline in annual consumption growth of 0.3 percentage points.
} 
None of these papers has, however, examined the contemporaneous impact of declining debt ratios on consumption or saving. ${ }^{8}$ Without challenging the view that too much debt can weigh on consumption, results of this paper suggest that deleveraging does not translate into higher saving rates or lower consumption growth for the average economy. Only consumer credit deleveraging is found to be associated with higher saving rates. This suggests that if countries were tightening financing conditions on new mortgages to bring household debt-toincome ratios to more sustainable levels, this would not necessarily translate into lower consumption growth. ${ }^{9}$

The rest of the paper proceeds as follows. Section II presents a brief definition of household deleveraging. Section III discusses the relationship between saving and credit, explaining why saving rates and changes in debt ratios may be empirically correlated and why the strength of this relationship may vary across economies. Section IV introduces the empirical approach. Econometric results are presented and discussed in Section V. Section VI concludes the paper.

\section{Definition OF Household Deleveraging}

Episodes of household deleveraging are traditionally defined as periods of declining debt-toincome ratios over several years. Strictly speaking, household deleveraging refers to a decline of the debt-to-asset ratios. It is, however, generally analyzed based on debt-to-income ratio. The value of assets is much more volatile than the value of debt, and debt-to-asset ratios can offer a misleading picture of household debt sustainability. Debt-to-income ratios are also more relevant as in normal times, households are paying down their debt with their income, not with their wealth (a significant part of which being in housing and is therefore illiquid) while households do not seem in practice to target a given level of leverage (as evidenced by McCarthy and McQuinn, 2017). Finally, data on household non-financial assets are only available for a limited number of countries so that deleveraging episodes are generally identified using debt-to-income ratios.

Historically, household deleveraging in advanced and emerging economies lasted more than 4 years for a decline of the debt ratio of 14 percentage points on average. These numbers,

\footnotetext{
${ }^{8}$ Mian et al. (2017) find for a sample of 30 countries that a rise in the household debt-to-GDP ratio is boosting short-term growth but is reducing medium-term growth (boom-bust pattern). Conversely, a decline in household debt does not lead to higher subsequent growth. Lombardi et al. (2017) obtain similar results for 54 economies, with the long-run negative effects of debt eventually outweighing their short-term positive effects. These papers, however, focus on the lead-lag relationship between changes in debt ratios and macroeconomic performance, and do not investigate the immediate effects of lower debt ratios on consumption or growth. The present paper focuses on the contemporaneous relationship between household deleveraging and saving. A similar paper is Cooper (2012) who finds little evidence that deleveraging affected household consumption in the United States. While the consumption growth of households who reduced their debt was lower than the consumption growth of other households, this pattern is essentially the same prior to and during the GFC.

${ }^{9}$ This policy might still reduce housing prices and lead to negative wealth effects, weighing on consumption. These wealth effects tend however to be marginal compared to effects from other determinants of consumption and might be more than outweighed by the supportive effects from lower "forced saving" related to lower debt repayments on new mortgages.
} 
however, hide a significant variation across episodes (Table 1). For instance, in the 1990s, the United Kingdom experienced a decline of its debt ratio of only 8.3 percentage points over 6 years while in Denmark, Finland, Norway, and Sweden, household deleveraging lasted between 6 and 8 years, with drops of debt ratios of between 25 and more than 50 percentage points of disposable income. Despite significant downward adjustments, in the vast majority of cases, debt ratios did not return to their pre-boom levels, possibly reflecting structural effects from financial market liberalization.

Table 1 - Changes in household debt ratios and saving rates during full boom-bust credit cycles (percentage points of disposable income)

\begin{tabular}{|c|c|c|c|c|c|c|c|c|c|c|}
\hline \multirow[b]{2}{*}{ Country } & \multirow[b]{2}{*}{ Peak } & \multirow[b]{2}{*}{ Trough } & \multicolumn{4}{|c|}{ 5-year boom period before deleveraging } & \multicolumn{4}{|c|}{ From peak to trough } \\
\hline & & & $\begin{array}{l}\Delta \text { Debt- } \\
\text { to-income } \\
\text { ratio }\end{array}$ & $\begin{array}{c}\text { Net credit } \\
\text { effect }\end{array}$ & $\begin{array}{c}\text { Nominal } \\
\text { growth } \\
\text { effect }\end{array}$ & $\begin{array}{l}\text { Average } \\
\text { gross } \\
\text { saving-to- } \\
\text { income } \\
\text { ratio }\end{array}$ & $\begin{array}{l}\Delta \text { Debt- } \\
\text { to-income } \\
\text { ratio }\end{array}$ & $\begin{array}{l}\text { Net credit } \\
\text { effect }\end{array}$ & $\begin{array}{c}\text { Nominal } \\
\text { growth } \\
\text { effect }\end{array}$ & $\begin{array}{l}\text { Average } \\
\text { gross } \\
\text { saving-to- } \\
\text { income } \\
\text { ratio }\end{array}$ \\
\hline AUS & 1988 & 1990 & 19.1 & 36.9 & -17.8 & 17.8 & -6.1 & 8.5 & -14.6 & 16.6 \\
\hline AUT & 2010 & 2014 & 4.6 & 11.6 & -7.0 & 16.4 & -3.2 & 4.8 & -8.0 & 13.2 \\
\hline BEL & 1999 & 2001 & 7.2 & 12.5 & -5.2 & 18.7 & -5.6 & 0.7 & -6.3 & 17.5 \\
\hline CAN & 1972 & 1974 & 7.8 & 25.8 & -18.0 & 14.0 & -5.7 & 15.1 & -20.8 & 19.1 \\
\hline CAN & 1979 & 1982 & 10.0 & 34.2 & -24.2 & 19.5 & -13.3 & 10.2 & -23.4 & 20.6 \\
\hline CHE & 1987 & 1993 & 32.9 & 57.7 & -24.8 & n.a. & -17.9 & 37.1 & -55.0 & n.a. \\
\hline $\mathrm{CHE}$ & 2005 & 2008 & 20.5 & 27.3 & -6.9 & 18.4 & -6.1 & 14.7 & -20.8 & 20.2 \\
\hline DNK & 1987 & 1994 & 62.0 & 87.6 & -25.6 & 6.3 & -27.5 & 29.8 & -57.2 & 6.5 \\
\hline ESP & 1989 & 1995 & 17.3 & 33.8 & -16.6 & 4.5 & -1.6 & 21.9 & -23.5 & 6.2 \\
\hline FIN & 1989 & 1997 & 26.8 & 44.5 & -17.7 & 7.7 & -30.8 & -10.1 & -20.7 & 11.1 \\
\hline GBR & 1990 & 1996 & 18.0 & 44.4 & -26.4 & 9.7 & -8.3 & 23.0 & -31.2 & 13.4 \\
\hline GBR & 2007 & 2015 & 26.1 & 49.1 & -23.0 & 8.0 & -24.5 & 12.8 & -37.3 & 9.8 \\
\hline ISR & 2008 & 2012 & 5.5 & 26.8 & -21.4 & -3.8 & -6.3 & 15.4 & -21.7 & -1.3 \\
\hline JPN & 1990 & 1994 & 20.9 & 40.1 & -19.2 & 21.0 & -16.1 & -2.8 & -13.3 & 21.4 \\
\hline JPN & 2005 & 2012 & -0.9 & -1.6 & 0.7 & 11.3 & -8.1 & -9.8 & 1.8 & 11.4 \\
\hline KOR & 1997 & 1998 & 16.6 & 45.0 & -28.4 & 21.2 & -12.7 & -8.7 & -3.9 & 26.2 \\
\hline $\mathrm{KOR}^{*}$ & 2002 & 2004 & 27.4 & 39.1 & -11.6 & 9.1 & -5.2 & 8.8 & -14.0 & 10.2 \\
\hline LTU & 2008 & 2013 & 41.4 & 46.7 & -5.3 & 3.4 & -12.3 & -9.0 & -3.3 & 4.6 \\
\hline NLD* & 1982 & 1985 & 4.4 & 12.8 & -8.4 & 15.3 & -4.9 & 4.0 & -8.8 & 15.3 \\
\hline NOR & 1988 & 1995 & 51.1 & 81.8 & -30.7 & 5.7 & -49.5 & 3.2 & -54.2 & 9.5 \\
\hline NZL & 2008 & 2011 & 28.7 & 55.5 & -26.8 & 0.3 & -17.3 & 7.1 & -24.4 & 5.6 \\
\hline RUS & 2008 & 2010 & 15.1 & 19.0 & -3.9 & 7.4 & -4.2 & 0.2 & -4.3 & 9.9 \\
\hline SWE & 1988 & 1995 & 32.6 & 61.6 & -29.0 & 0.0 & -55.7 & 3.8 & -59.5 & 4.4 \\
\hline USA & 1967 & 1970 & 2.2 & 18.8 & -16.6 & 15.5 & -6.2 & 8.5 & -14.7 & 15.7 \\
\hline USA & 1979 & 1982 & 9.3 & 28.9 & -19.6 & 16.0 & -5.7 & 11.9 & -17.7 & 16.7 \\
\hline ZAF* $^{*}$ & 1997 & 2002 & 1.3 & 12.6 & -11.2 & 5.0 & -10.6 & 12.2 & -22.7 & 4.3 \\
\hline
\end{tabular}

Sources: OECD, national central banks, and author's calculations.

Notes: The change in the debt-to-income ratio is decomposed into a net credit effect $\frac{D e b t_{t+T}-D e b t_{t}}{Y^{d}{ }_{t+T}}$ and a nominal growth effect $-\frac{Y^{d}{ }_{t+T}-Y^{d} t}{Y^{d}{ }_{t}} \times \frac{D e b t_{t}}{Y^{d}{ }_{t+T}}$. Minor debt decline episodes (Belgium 1994-1995, France 2012, and Switzerland (2000-2001) are not reported.

*: Changes and averages during the boom phase are computed two years before the peak due to data availability in the cases of the Netherlands and South Africa and to avoid because of episodes overlap in the case of Korea. 
Deleveraging can occur through lower debt, higher economic growth, or higher inflation, as noted by Tang and Upper (2010). It is, however, quite rare that household debt-to-disposable income ratios decrease because of a fall in the absolute level of debt, also called "active deleveraging" (Dossche et al., 2018). Deleveraging occurs instead through credit growth lagging behind nominal income growth, the so-called "passive deleveraging" (as shown in Table 1 where the change of the debt-to-income ratio is decomposed into a net credit effect and a nominal growth effect). ${ }^{10}$

Table 2 - Changes in household debt ratios and saving rates 5 years before the peak and from the peak to 2019 in selected ongoing deleveraging economies (percentage points of disposable income)

\begin{tabular}{|c|c|c|c|c|c|c|c|c|c|}
\hline \multirow[b]{2}{*}{ Country } & \multirow[b]{2}{*}{ Peak } & \multicolumn{4}{|c|}{ 5-year boom period before deleveraging } & \multicolumn{4}{|c|}{ From peak to 2019} \\
\hline & & $\begin{array}{l}\Delta \text { Debt- } \\
\text { to-income } \\
\text { ratio }\end{array}$ & $\begin{array}{l}\text { Net credit } \\
\text { effect }\end{array}$ & $\begin{array}{c}\text { Nominal } \\
\text { growth } \\
\text { effect }\end{array}$ & $\begin{array}{l}\text { Average } \\
\text { gross } \\
\text { saving-to- } \\
\text { income } \\
\text { ratio }\end{array}$ & $\begin{array}{l}\Delta \text { Debt- } \\
\text { to-income } \\
\text { ratio }\end{array}$ & $\begin{array}{c}\text { Net credit } \\
\text { effect }\end{array}$ & $\begin{array}{c}\text { Nominal } \\
\text { growth } \\
\text { effect }\end{array}$ & $\begin{array}{l}\text { Average } \\
\text { gross } \\
\text { saving-to- } \\
\text { income } \\
\text { ratio }\end{array}$ \\
\hline AUT & 2016 & -1.3 & 8.8 & -10.1 & 13.1 & -2.1 & 6.1 & -8.2 & 13.3 \\
\hline DEU* & 2000 & 18.4 & 26.1 & -7.8 & 16.5 & -22.2 & 17.7 & -39.8 & 17.2 \\
\hline DNK & 2009 & 73.1 & 106.0 & -32.9 & 5.4 & -74.8 & 11.2 & -86.1 & 9.1 \\
\hline ESP & 2007 & 51.1 & 74.7 & -23.6 & 8.6 & -41.6 & -21.6 & -19.9 & 7.6 \\
\hline GRC & 2013 & 30.2 & -1.5 & 31.7 & 1.5 & -20.5 & -19.5 & -1.0 & -5.2 \\
\hline $\mathrm{HRV}^{* *}$ & 2008 & 28.6 & 38.2 & -9.5 & 7.6 & -9.1 & -6.6 & -2.5 & 12.5 \\
\hline HUN & 2010 & 29.9 & 36.0 & -6.2 & 10.8 & -36.2 & -6.4 & -29.8 & 11.7 \\
\hline IRL & 2009 & 68.7 & 101.2 & -32.5 & 10.6 & -99.7 & -53.1 & -46.7 & 10.5 \\
\hline ITA & 2012 & 9.3 & 8.7 & 0.6 & 12.0 & -2.8 & 3.0 & -5.8 & 10.5 \\
\hline NLD & 2010 & 28.5 & 56.6 & -28.1 & 11.1 & -43.5 & 7.4 & -51.0 & 15.6 \\
\hline POL & 2015 & 6.4 & 14.8 & -8.5 & 2.5 & -2.3 & 10.6 & -12.9 & 3.1 \\
\hline PRT & 2011 & 9.3 & 20.4 & -11.1 & 8.7 & -32.8 & -13.9 & -19.0 & 7.5 \\
\hline TUR** & 2013 & 7.8 & 17.1 & -9.3 & 10.0 & -3.5 & 8.1 & -11.6 & 14.1 \\
\hline USA & 2007 & 26.7 & 50.9 & -24.2 & 9.9 & -34.9 & 11.0 & -46.0 & 12.2 \\
\hline
\end{tabular}

Sources: OECD, national central banks, and author's calculations.

Notes: The change in the debt-to-income ratio is decomposed into a net credit effect $\frac{D e b t_{t+T}-D e b t_{t}}{Y^{d}}$ and a nominal growth effect $-\frac{Y^{d}{ }_{t+T^{-}} Y^{d} t}{Y^{d}} \times \frac{D e b t_{t}}{Y^{d}{ }_{t+T}}$

* German deleveraging represents a specific case driven by structural factors (in particular, the country reunification), with a debt ratio being on a declining trend since 2000, although a slight increase has been observed from 2018 .

** Information up to 2016 for Croatia and 2017 for Turkey.

\footnotetext{
${ }^{10}$ The change of the debt-to-income ratio between the dates $t$ and $t+T$ can indeed be decomposed into a change in the level of debt (a "net credit effect" as represented by the first term of the right-hand side) and a change in nominal income growth (a "nominal income growth effect" represented by the second term) as follows:
}

$$
\left(\frac{D e b t}{Y^{d}}\right)_{t+T}-\left(\frac{D e b t}{Y^{d}}\right)_{t}=\frac{D e b t_{t+T}-D e b t_{t}}{Y_{t+T}^{d}}-\frac{Y_{t+T}^{d}-Y_{t}^{d}}{Y_{t}^{d}} \times \frac{D e b t_{t}}{Y_{t+T}^{d}} .
$$


Stagnant or declining debt levels have indeed been more common in the ongoing deleveraging episodes observed in some economies since 2007 (Table 2), ${ }^{11}$ although this has mainly happened in the early phase of the deleveraging, with a sharp contraction of credit volume and low nominal income growth. In the United States for example, the level of nominal debt decreased between 2007 and 2011 (by 4.1 percent in cumulative terms) but has since then increased again each year so the decrease in the debt-to-disposable income ratio has been exclusively driven by debt growth lagging behind nominal income growth. Another observation worth noting is that the ongoing deleveraging episodes are much lengthier than the ones of the 1980s and 1990s, reflecting the ultra-accommodative financing conditions prevailing in the wake of the GFC.

The change in the level of household debt can itself be decomposed into inflows, that is new borrowings, and outflows, which include debt repayments and defaults:

$\Delta$ Debt $=$ New Loans - Debt Repayments - Debt Defaults.

In general, available data do not allow distinguishing between these three components. ${ }^{12}$ One exception is the United States where the Federal Reserve Bank of New York's Consumer Credit Panel offers detailed information on consumer debt and loan performance. According to these individual credit records data, new loans appear as the main driver of the evolution of debt. The after-GFC decline in household debt in the United States is found to be mainly explained by lower credit growth rather than by expanding debt repayments and mortgage defaults.

Even if debt repayments and defaults had not grown since 2007, mortgage debt in the United States would have declined over the 2009-11 period because of a material drop in new borrowings, mainly reflecting a dramatic decline in first-time homebuying (Bhutta, 2015). The key role of new borrowings in driving debt levels is confirmed by Knotek and Braxton (2012). Differentiating between the number of consumers taking on more debt and the dollar amount by which individual consumers are changing their debt levels, the authors report that

\footnotetext{
${ }^{11}$ Note that the debt ratio in Switzerland experienced a downward adjustment over 2006-2008 as reported in Table 1, but has since then increased again and is now exceeding its 2005 peak. Norway experienced a significant drop in nominal disposable income in 2006, leading to a sharp increase in its debt ratio. To limit this outlier effect, the 2006 gross disposable income is replaced by the average of 2005 and 2007 values.

${ }^{12}$ Strictly speaking, the third term of the relationship (1), "Debt Defaults", should be replaced by "ChargeOffs", as the outstanding level of debt will decrease only after the creditor declares that the amount of debt is unlikely to be collected. It can also be noted that in some countries "Debt Defaults" did not play a significant role but that the main forces at work during the deleveraging have been equivalent to partial defaults or chargeoffs. In Hungary for instance, household debt first increased in the run-up to the GFC partly because a large share of residential mortgages were denominated in foreign currency (euro or Swiss francs). The deleveraging was then in large part due to administrative measures, including the opportunity for households to repay foreign exchange-denominated loans at below-market exchange rates between November 2011 and January 2012; and later, by a substantial reduction in principals when foreign exchange mortgages were converted to local currency (Hungarian Forint) contracts. In both cases, the adjustment was essentially a windfall to debtors and equivalent to a partial charge-off.
} 
the bulk of deleveraging has occurred through a sharp decline in the number of consumers taking on additional debt.

Finally, although defaults are playing a smaller role than new borrowings in the evolution of debt, they still explain nearly 30 percent of the debt decline in the United States over 20082011 (Bouis et al., 2013). ${ }^{13}$ The overall contribution to household deleveraging may be even larger as rising charge-offs increase losses of the banking sector, leading to a tightening of credit conditions and a reduction of new loans (Koo, 2011 and Li and Patwari, 2012).

\section{The Relationship Between CREdit AND SAVING}

Historically, episodes of credit busts are often associated with an increase in saving rates (Figure 1). The nature of the relationship between the change in household debt and saving remains, however, largely unexplored and it is useful to discuss the influence on saving of each of the three drivers of the stock of debt appearing in relation (1). First, it must be noted that rising debt defaults cannot account for the positive relationship between deleveraging and saving rates as defaults may actually increase rather than dampen consumption by freeing up resources available for households' expenditures (Cooper, 2012).

Second, although higher debt repayments mechanically translate into higher saving, they are unlikely to explain why saving increases during deleveraging, as in practice the decline in debt ratios at the macroeconomic level is not explained by higher debt repayments, as seen above. Moreover, arguing that households significantly raise their debt repayments in bad times, as claimed by some observers, ${ }^{14}$ seems counter-intuitive. There is some evidence that households may increase debt repayments to reduce their debt more quickly, but this only applies to a small portion of indebted households who can afford deleveraging by higher debt repayments. ${ }^{15}$ During the deleveraging phase, the majority of households (who do not

\footnotetext{
${ }^{13}$ This estimate of the magnitude of the contribution of defaults to debt reduction is lower than the two-thirds number reported in MGI (2012) or Cooper (2012). This is because it only considers the contribution from the crisis-related increase in charge-offs (see Bouis et al., 2013, footnote 8, for details).

${ }^{14}$ For instance, Svensson (2012) notes that Riksbank advocates of "leaning against the wind" have stated that to restore debt-to-asset ratios in face of declining housing prices, households may "(...) want to pay off some of their debt to come down to a more suitable level. This means they will prioritise saving over consumption." Likewise, Dombret (2013) claims that when "the value of the assets held by the private sector fall, while the value of the liabilities remains the same (...) households and enterprises are compelled to increase their saving in order to pay off their debts."

${ }^{15}$ For Ireland, McCarthy and McQuinn (2017) report on the basis of a survey of 2,000 households from May 2012 to February 2013, that less than 7 percent of respondents made overpayments to clear their debt more quickly or used savings to supplement their payments. Those households had besides higher income and wealth (larger savings or investments) than those who did not deleverage, in line with the finding by the authors that the main criterion affecting the decision to deleverage is the ability to repay rather than the degree of indebtedness. Consumption of these households was negatively affected, though by a very small amount. Using data on mortgage loans originated during the 2005-2007 period in the United States, Di Maggio et al. (2017) find that following a drop in monthly mortgage payments reflecting lower interest rates, U.S. households increase both their consumption and their debt repayments to deleverage from high levels of debt accumulated during the boom years. However, borrowers' responses to rate reductions differ significantly depending on
} 
default) are instead more likely to keep paying down debt at a similar pace as they do in normal times and to significantly reduce their new borrowings. This implies that understanding the effect of deleveraging on saving rates requires examining the relationship between new borrowings and saving.

As pointed out by Dynan (2012), in traditional models saving is determined by income, wealth, preferences, uncertainty, and the return on saving, but credit does not exert an independent effect. On the accounting side, the following identity still suggests a possible relationship between saving and the change in debt:

$$
\begin{aligned}
S & \equiv \Delta \text { Financial Assets }+\Delta \text { Real Assets }-\Delta \text { Financial Liabilities } \\
\Leftrightarrow S & \equiv \Delta \text { Financial Assets }+\Delta \text { Real Assets }-(\text { NewBorrowings }- \text { Debt Repayments }),
\end{aligned}
$$

where $S$ denotes household saving, $\Delta$ Financial Assets is the net acquisition by households of financial assets (excluding valuation effects), $\Delta$ Real Assets is household investment in housing and their acquisition of existing houses and land from other institutional sectors ( $\Delta$ Real Assets is also known as household gross fixed capital formation $I$, excluding valuation effects, like for other items of the identity), and $\Delta$ Financial Liabilities is net borrowings, that is new borrowings minus debt repayments. ${ }^{16}$

Identity (2) indicates that at the aggregate level, an increase in net borrowings can finance consumption (i.e., lower saving), investment, or the acquisition of financial assets. Nothing ensures, however, that rising debt is used to finance higher consumption as it can instead simply be used for the acquisition of financial assets or the financing of investment. For instance, Nickel (2004) reports that in the United Kingdom both the rate of accumulation of financial liabilities and of financial assets rose together over 1998-2004. Consequently, the proportion of post-tax household income which is consumed remained stable over the same period, suggesting that there is no strong relationship between aggregate consumption growth and aggregate debt accumulation.

Higher indebtedness consecutive to higher house prices could even be associated with lower consumption and higher saving, according to a "forced saving" argument. Günes and Tunc (2018) find for the United States (using the Panel Study Income Dynamics data over the 1999-2015 period) that mortgage repayments - which can be considered as "forced saving") crowd out financial saving, including when considering only the payments of the mortgage principal (that is excluding interest payments, which are part of consumption). Because this "forced saving" in real estate is less liquid than financial saving (which includes saving in safe assets), larger mortgage repayments could weigh on household consumption, especially as debt repayments cannot be adjusted downwards in face of a negative shock on household income, contrary to financial saving.

income and wealth, with poorer borrowers deleveraging less than others to leave more resources available to consume.

16 This identity is inspired from Nickell (2004) and from Pistaferri (2016). 
Another reason why higher house prices and mortgage debt could imply larger saving, contrary to the traditional housing wealth effect, relates to the "down-payment channel". Balta and Ruscher (2011) note that higher house prices can force credit-constrained households who wish to acquire a house to accumulate more savings in order to cover a higher down-payment. Estimates for the euro area suggest that this down-payment effect tends to dominate in the medium term the traditional housing wealth channel, translating into an overall negative impact of higher house prices on consumption.

\section{A. Why Deleveraging and Saving Rates are Empirically Positively Correlated}

Even in the absence of a mechanical link between saving rates and changes in debt ratios, several factors, directly or indirectly related to the evolution of indebtedness, can explain why saving rates rise in deleveraging periods:

- First, credit has a direct influence on saving under the hypothesis of liquidity-constrained households borrowing to smooth transitory income shocks. When credit conditions tighten, as is typically the case in deleveraging periods (see Bhutta, 2015 and Gropp et al., 2019 for empirical evidence for the United States), households cannot borrow as easily as before to offset negative income shocks and have to increase their buffer-stock savings (Carroll, 2001). ${ }^{17}$ In line with this hypothesis, empirical analyses find that credit market liberalization played a significant role in the steady decline of saving rates observed since the early 1980s (e.g., Loyaza et al., 2000). ${ }^{18}$ Studies also find that shortterm changes in credit availability partly explain business-cycle fluctuations of saving (e.g., Carroll et al., 2019);

- Second, fast-rising nominal income contributes to passive deleveraging, and, if driven by real income growth, also increases saving rates;

- Third, household deleveraging tends to be accompanied by house price declines and other asset depreciations (Figure 2) that in turn impact consumption through wealth effects. Such effects, which do not appear in identity (2) as national accounting aggregates are measured net of valuation effects, are estimated to significantly affect saving (although consensus on the economic importance of these wealth effects has not yet been reached, see Cooper and Dynan, 2015, for a survey). Carroll et al. (2019) for instance identify the collapse in household wealth as the largest contributor to the decline in consumption in the United States during the Great Recession;

- Fourth, deleveraging is associated with declining house prices and therefore, with a lower availability of home equity-based borrowing, reducing consumption (Mian and Sufi, 2011b). The economic impact of housing equity withdrawal (HEW) on consumption is, however, controversial. Whether the proceeds from HEW drive consumption or whether

\footnotetext{
17 "Saving" in singular usually refers to the flow variable, that is to the portion of income that is not spent over a given period, while "savings" in plural refers to the stock of wealth accumulated over several periods.

${ }^{18}$ Mortgage credit liberalization also contributed to the long-term decline of saving rates by reducing the minimum deposit required for first-time homebuyers (Muellbauer, 2008).
} 
the correlation between HEW and consumption results from the wealth effect of rising property prices remains uncertain. In addition, the share of home-equity based borrowing used for consumption purpose may be relatively marginal in some countries (Menegatti and Roubini, 2007);

- Finally, deleveraging and credit busts are often associated with depressed labor markets and higher economic uncertainty (Figure 2) leading to higher precautionary saving. Mody et al. (2012) estimate for instance that at least two-fifths of the increase in saving observed in 2007-2009 in OECD countries is due to higher unemployment risk and GDP volatility.

While the first factor (the liquidity-constrained households' hypothesis) implies a causal relationship running from credit to saving, credit does not play a direct role in the case of the last three factors. Identifying the direct influence of credit on saving therefore requires to properly control for effects indirectly related to changes in debt ratios.

\section{Figure 2 - Changes of macroeconomic variables around historical debt turning points}

Change of real house prices during the deleveraging (percent)

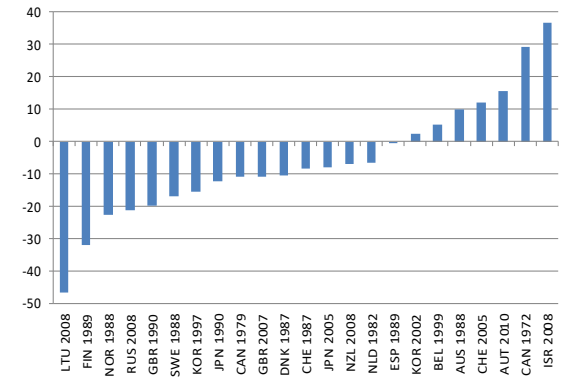

Change of the unemployment rate during the deleveraging (percentage points)

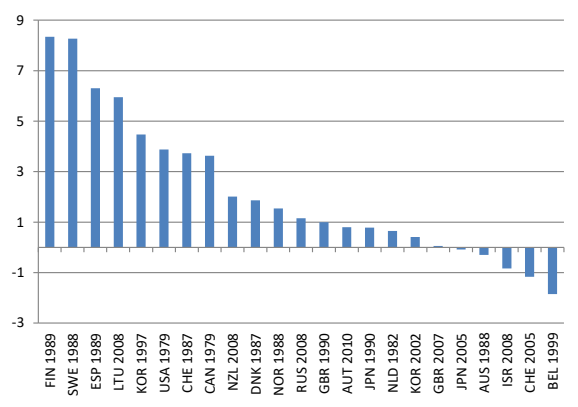

Change of average annual growth rate of real stock prices between boom and bust (percentage points)

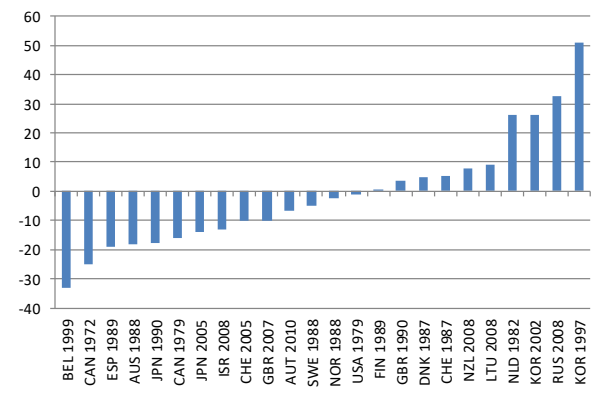

Change of average annual GDP growth volatility (declining growth) between boom and bust (percentage points)

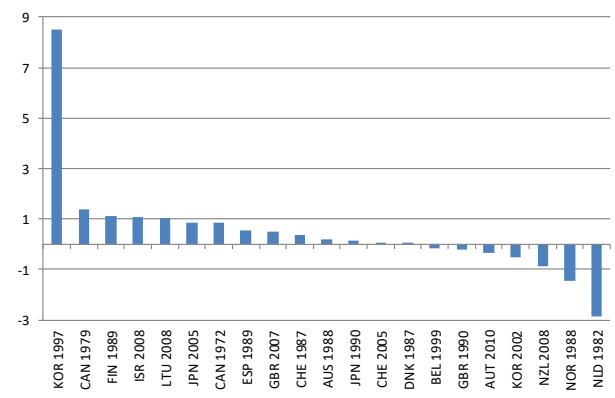

Sources: OECD, national central banks, Datastream, and author's calculations.

Note: Changes in real house prices and in unemployment rates are computed from the peak to the trough of the debt ratio. Averages of annual growth rates of real stock prices and of GDP growth volatility (declining growth) are computed over 5 years before the decline of the debt ratio (boom phase) and from the peak to the trough (bust phase). GDP growth volatility is multiplied by a dummy equal to one if real GDP growth is declining, and zero otherwise. The sample is composed of the historical credit boom and bust episodes reported in Table 1, with years referring to peaks of the debt ratios. 


\section{B. Implications in Terms of Cross-Country Heterogeneity}

Several credit market features and other country-specific settings potentially affect the transmission of credit to saving implying that the strength of the credit-saving relationship may vary across economies. These settings include:

- The share of consumer credit in disposable income. Expansion in consumer credit is strongly associated with consumption growth (e.g., Bacchetta and Gerlach, 1997) and its importance in the economy is expected to strengthen the link between saving and credit. Although the evolution of household debt is mainly driven by mortgage debt, consumer and mortgage credits are highly correlated (Chmelar, 2013) and the change of total debt is likely to be accompanied by a change in consumer debt in the same direction, with immediate effects on the consumption of liquidity-constrained households. ${ }^{19}$

- The availability of housing equity withdrawal (HEW) to borrow against accumulated house equity. Greater "liquidity" of housing equity is indeed associated with a higher impact of housing sector activity on the rest of the economy by increasing the financial accelerator effect of rising house prices on consumption (see IMF, 2008, for some crosscountry evidence).

- Home ownership rates may raise the macroeconomic effects of housing wealth effects and HEW. Campbell and Cocco (2007) find microeconomic evidence of a positive effect of house prices on consumption for the cohort of old households who are homeowners, and an effect that is close to zero for the cohort of young households who are renters. The level of homeownership is, however, not a sufficient condition, as noted by Catte et al. (2004) who report a weak cross-country correspondence between owner-occupation and the sensitivity of consumption to real house prices.

- The level of the saving rate in conjunction with the degree of liquidity of household assets (as reflected by the presence of "illiquid" tax-deferred saving/pension accounts) may impact the relationship between borrowing and saving. As outlined by Menegatti and Roubini (2007), when households have low or negative saving and limited liquid assets, consumption cannot be increased in response to a positive wealth effect (or any exogenous shock) by reducing saving or financial assets and the only way for households to raise consumption is to increase financial liabilities.

- Arrangements to limit the costs for households to default on their debt may cushion the impact of deleveraging on saving rates. As stressed by Cooper (2012), households' cessation of mortgage payments actually raises the amount of income that is available for non-housing related expenditures and households may choose to default rather than reduce consumption. This "financial decelerator" mechanism (Elul, 2008) may partly explain why the damping effect of deleveraging on consumption estimated for the United

\footnotetext{
${ }^{19}$ Mortgage debt includes all loans for the purchase of real estate and home equity loans while consumer credit consists in general of credit card debt, student loans, auto loans, and credit used for the purchase of other durable goods.
} 
States during the GFC, although non-negligible, is relatively modest (Dynan, 2012), in particular in comparison with the consumer spending collapse observed in 1930, before institutional changes lowered the cost of default by 1938 (Olney, 1999). Information on the rights of lenders to pursue a borrower's assets (other than the house securing the mortgage) in case of a default, known as lender recourse on mortgages, can be used instead of information on household debt write-down arrangements which is in general not available. Full recourse on mortgages tends to increase borrowers' incentives to honor the terms of the contract and has been associated with lower default rates (Cerutti et al., 2017).

As shown in Table 3, countries can differ significantly with respect to the above-mentioned characteristics, possibly implying a different response of saving to changing debt ratios across economies. $^{20}$

\section{EMPIRICAL APPROACH}

This section introduces the empirical approach, presenting the variables and the econometric specification.

\section{Variables}

The dependent variable is the household gross saving rate. The explanatory variable of interest is the change of the household ratio of total financial liabilities to gross disposable income. ${ }^{21}$ Regressions include as controls the usual determinants of saving identified in literature:

- Income-related variables, namely the level and the growth rate of real disposable income and the terms of trade, are expected to be positively related to saving rates as households tend to increase their saving when they become richer or their income grows faster (Lyoza et al., 2000);

- The old and young-age dependency ratios are included to account for the existence of demographic structure effects;

\footnotetext{
${ }^{20}$ Full recourse is observed in most countries of my sample. This echoes the observation of Jordà et al. (2020), that restructuring or liquidation arrangements for household debt remain largely underdeveloped in most countries, in contrast to what prevails for corporate debt.

${ }^{21}$ A detailed description of the construction of the debt variable is presented in the appendix of Bouis et al. (2013). The household sector refers in this paper to the aggregate account of households and non-profit institutions serving households (NPISHs) as data for the household sector alone are rarely available. The BIS database on credit to non-financial private sector (described in Dembiermont et al., 2013) also offers a measure of household indebtedness which is however in general more restrictive than the total financial liabilities variable considered here as it does not incorporate a number of items (namely "Securities other than shares" i.e. Financial derivatives; "Shares and other equity"; "Insurance technical reserves" which includes "Net equity of households in life insurance and pension funds reserve", and "Other account payables"). Importantly, for some countries, only loans from domestic financial institutions are covered. Still, the BIS debt variable represents on average more than 90 percent of total financial liabilities and the evolutions of the two debt measures are strongly correlated. The BIS debt variable is used as a source of information for countries without national account statistics.
} 
- The cyclically-adjusted government net lending as a percentage of potential GDP, which is found to significantly explain OECD saving rates in previous panel regressions (e.g., Röhn, 2010), is incorporated to control for Ricardian equivalence effects;

- The unemployment rate, the inflation rate, and GDP growth volatility (based on a GARCH model measure, following Mody et al., 2012), used as proxies of income and macroeconomic uncertainty, are expected to increase saving rates for precautionary motives;

Table 3 - Differences in credit market features, homeownership rates, and pension funds (numbers in percent)

\begin{tabular}{|c|c|c|c|c|c|}
\hline Country & $\begin{array}{l}\text { Consumer credit-to- } \\
\text { disposable income ratio } \\
(2000-19 \text { average) }\end{array}$ & $\begin{array}{l}\text { Housing equity } \\
\text { withdrawal }\end{array}$ & $\begin{array}{c}\text { Homeownership } \\
\text { rate }^{1}\end{array}$ & $\begin{array}{l}\text { Share of pension } \\
\text { funds in GDP } \\
(2009-19 \text { average })\end{array}$ & $\begin{array}{c}\text { Full } \\
\text { recourse }^{2}\end{array}$ \\
\hline Australia & 15.8 & Yes & 68.5 & 112.3 & Yes \\
\hline Austria & 12.1 & No & 56.5 & 5.5 & Yes \\
\hline Belgium & 8.9 & No & 72.3 & 28.9 & Yes \\
\hline Brazil & - & No & 74.2 & 18.7 & No \\
\hline Canada & 42.2 & Yes & 66.7 & 141.0 & Yes \\
\hline Chile & 14.1 & Yes & 60.0 & 66.5 & Yes \\
\hline China & 38.3 & No & 89.8 & 1.2 & No \\
\hline Colombia & 12.5 & No & 51.0 & 20.1 & Yes \\
\hline Croatia & 6.4 & No & 89.7 & 20.2 & Yes \\
\hline Czech Republic & 6.7 & No & 77.6 & 7.4 & Yes \\
\hline Denmark & 13.4 & Yes & 65.0 & 192.5 & Yes \\
\hline Finland & 11.2 & Yes & 73.0 & 61.9 & Yes \\
\hline France & 12.3 & No & 63.3 & 9.3 & Yes \\
\hline Germany & 10.4 & No & 52.5 & 6.4 & Yes \\
\hline Greece & 17.1 & Yes & 75.3 & 0.4 & Yes \\
\hline Hungary & 14.7 & Yes & 88.0 & 6.3 & Yes \\
\hline Ireland & 17.7 & Yes & 72.6 & 43.0 & Yes \\
\hline Israel & 22.4 & No & 66.9 & 52.7 & Yes \\
\hline Italy & 5.4 & No & 73.0 & 7.8 & Yes \\
\hline Japan & 11.2 & Yes, but not largely & 61.3 & 29.5 & Yes \\
\hline Korea & 54.2 & Yes & 55.5 & 21.0 & No \\
\hline Lithuania & 3.7 & Yes & 90.9 & 5.7 & Yes \\
\hline Luxembourg & 11.1 & No & 72.0 & 2.5 & Yes \\
\hline Mexico & 6.0 & Yes, but only recently & 73.2 & 15.5 & No \\
\hline The Netherlands & 7.7 & Yes & 67.3 & 154.8 & Yes \\
\hline New Zealand & 11.5 & Yes & 64.6 & 20.8 & Yes \\
\hline Norway & & Yes & 83.6 & 8.9 & Yes \\
\hline Poland & 12.6 & Yes, but rarely used & 78.8 & 12.1 & Yes \\
\hline Portugal & 10.4 & No & 74.7 & 13.0 & No \\
\hline Russia & 18.2 & No & 85.3 & 5.6 & Yes \\
\hline Slovak Republic & 8.2 & Yes, but rarely used & 89.3 & 9.8 & Yes \\
\hline Slovenia & 10.7 & No & 78.5 & 6.5 & Yes \\
\hline South Africa & 19.5 & No & 59.6 & 87.7 & Yes \\
\hline Spain & 11.7 & No & 78.7 & 13.4 & Yes \\
\hline Sweden & 8.6 & Yes & 66.5 & 72.9 & Yes \\
\hline Switzerland & 4.0 & No & 43.4 & 127.0 & Yes \\
\hline Turkey & 9.0 & No & 60.4 & 1.8 & Yes \\
\hline United Kingdom & 16.9 & Yes & 67.7 & 97.1 & Yes \\
\hline United States & 23.1 & Yes & 66.0 & 131.1 & No \\
\hline
\end{tabular}

${ }^{1}$ Numbers are averages of data for 2001, 2006, 2016 for Australia; 2000 and 2010 for Brazil; 2013-2017 for Canada; 2017 for Chile; 2008 for Colombia; 2014 and 2018 for China; 2014 and 2017 for Israel; 2003, 2008, 2013 for Japan; 2005, 2010, 2015 for Korea; 2010 and 2016 for Mexico; 2006, 2013, 2018 for New Zealand; 2010-2018 for Rus sia; 2015, 2016, 2018 for South Africa; 2005-18 averages for European countries and for United States.

${ }^{2}$ Full recourse refers to the rights of lenders to pursue a borrower's assets, other than the house securing the mortgage in case of a default.

Sources: National central banks, National statistics institutes, and Eurostat, for consumer credit and homeownership rates. OECD Pension Markets in Focus 2020 for shares of pension funds in GDP. OECD (2005), Igan and Lougani (2012, Table 8) and national sources, for availability of housing equity withdrawal. Cerutti et al. (2017) for full recourse. 
- Financial variables include the real short-term interest rate and household wealth, proxied by household financial worth as a share of disposable income. Due to limited crosscountry data coverage, this measure of household wealth does not include housing wealth, which yet represents a significant share of household assets. To address this issue, regressions incorporate the growth rate of real house prices. Alternative specifications also use the growth rate of real stock market valuations given limited coverage of the household financial worth variable.

Data cover 39 countries over the period 1980-2019. Annual data of saving rates are of better quality than quarterly data while annual information on household debt offers a larger coverage across time, in particular for the deleveraging episodes of the 1980s. Description and sources of the data are provided in the appendix.

\section{Econometric specification}

I first estimate the following dynamic fixed-effects panel data equation:

$$
\begin{aligned}
& S_{i, t}=\alpha_{0} s_{i, t-1}+\alpha_{1} \ln R Y_{i, t}^{d}+\alpha_{2} \text { GRY Y }_{i, t}^{d}+\alpha_{3} \text { Trade }_{i, t}+\alpha_{4} \text { Old }_{i, t}+\alpha_{5} \text { Young }_{i, t}+\alpha_{6} U_{N R} R_{i, t} \\
& +\alpha_{7} \text { Inflation }_{i, t}+\alpha_{8} \text { Volatility }_{i, t}+\alpha_{9} \text { IRS }_{i, t}+\alpha_{10} \ln \left(\frac{\text { Debt }}{Y^{d}}\right)_{i, t}+\alpha_{11} \Delta\left(\frac{\text { Debt }}{Y^{d}}\right)_{i, t}+\eta_{i}+\gamma_{t}+\varepsilon_{i, t},
\end{aligned}
$$

where $s$ denotes the household gross saving rate, $R Y^{d}$ the real household gross disposable income (in PPPs), $G R Y^{d}$ the growth rate of the real household gross disposable income, Trade the terms of trade ratio, Old and Young are the old and young-dependency ratios, UNR the unemployment rate, Inflation the annual growth rate of the consumer price index, Volatility is a GARCH $(1,1)$ measure of GDP per capita growth volatility, IRS the real shortterm interest rate, Debt is the stock of household debt (or total financial liabilities), $Y^{d}$ the nominal household gross disposable income, $\eta_{i}$ and $\gamma_{t}$ are country and year fixed effects and $\varepsilon$ the error term. Household financial net worth and government net lending are considered in a second step of the analysis as including these variables in the regressions reduces the sample size due to limited time coverage in the 1980s.

I consider two estimators: the ordinary least squares dummy variable (LSDV) estimator and the system-GMM estimator (Arellano and Bover, 1995 and Blundell and Bond, 1998), where all the variables are treated as weakly exogenous with respect to the error term $\varepsilon$, except the young and old dependency ratios, the terms of trade, and time fixed effects, which are treated as strictly exogenous (following Loayza et al. 2000). ${ }^{22}$

\footnotetext{
22 The consistency of the system-GMM estimator depends on whether lagged values of the explanatory variables are valid instruments. I use two specifications tests to address this issue: the first is the Hansen test of overidentifying restrictions which tests the overall validity of the instruments; the second examines the hypothesis that the error term is not serially correlated, or in case of serial correlation, that it follows a finiteorder moving-average (MA) process. First-order serial correlation of the differenced error term is generally expected even if the error term in level is uncorrelated. Second-order serial correlation of the differenced error term indicates that the error term in levels is serially correlated and follows an MA(1) process. If the test fails to
} 
These two estimators have their pros and cons. The LSDV estimator can deliver biased estimates due to the well-known Nickell (1981) bias and the likely jointly endogeneity of some of the explanatory variables with the saving rate and consumption growth. The biascorrected LSDV estimator of Bruno (2005) could outperform the GMM estimators in terms of bias and root mean squared error (Bruno, 2005), especially for panel data with a small number of cross-sectional units but does not deal with the potential endogeneity of independent variables. The system-GMM estimator works well when the number of panel units is large and the time dimension is small. But for the typical size of a macroeconomic panel ( $T$ and $N$ are here close to 40), Monte Carlo simulations indicate that the Nickell bias created by using the LSDV estimator is more than offset by its greater precision compared to IV and GMM estimators (Attanasio et al. (2000) or Cecchetti et al. (2011)). Second, with GMM estimator, the set of available instruments is potentially large, and using too many instruments may weaken its effectiveness. This is particularly true in macroeconomic panels where the number of instruments can quickly exceed the number of countries, which sets the maximum limit recommended in the literature (Roodman, 2009) ${ }^{23}$ For this reason, only a sub-set of control variables can be used, especially when controlling for year fixed effects.

A third approach consists of using an external instrument for the change of the debt ratio. Mian et al. (2017), for example, consider the mortgage-sovereign spread. This variable, however, appears to be a weak instrument for my sample of observations. Zabai (2017) reports a similar issue when using a sample of countries different from the one used by Mian et al. (2017). Another candidate instrument could be macroprudential policy but again, the strength of this instrument seems highly sensitive to the sample composition. Alam et al. (2019) find for instance that household debt is related to some macroprudential policy measures of the IMF integrated Macroprudential Policy (iMaPP) database, but this holds mainly when considering a large sample of advanced and emerging market economies, while only a few countries actively used macroprudential policy to address household indebtedness. In many cases, the active deleveraging observed in the early phase of the deleveraging is probably explained by a repricing of risk by banks rather than by a tightening of borrowerbased and/or lender-based macroprudential measures. ${ }^{24}$

\section{ESTIMATION RESUlts}

This section presents the econometric results. It first discusses estimates of the baseline specification in which the effect on saving of the change of the debt-to-income ratio is decomposed into rising and declining indebtedness. Section B discusses cross-country

reject the null hypothesis of absence of second-order correlation, the original error term is serially uncorrelated and the corresponding moment conditions are used.

${ }^{23}$ In general, I am here considering one lag as instrument of variables while collapsing the instrument matrix into one column, following recommendations by Roodman (2009).

${ }^{24}$ Arena et al. (2020) report that macroprudential policy implemented in recent years by European countries has been mainly effective in strengthening resilience and containing systemic financial risks rather than in containing the growth of house prices and of overall credit in a context of still-accommodative monetary policy. 
heterogeneity and the role of institutional and credit market institutions in the relationship between deleveraging and saving. Section $\mathrm{C}$ analyzes the contributions of the respective changes of consumer credit and of mortgages in the deleveraging-saving relationship.

\section{A. Baseline Regressions}

Columns (1) to (5) of Table 4 present results of the baseline equation for the saving rate using the LSDV estimator and the full sample of observations. Traditional determinants considered in the literature are generally significant with the expected signs. The lagged household saving rate has a positive and significant coefficient with a large degree of persistence (estimated coefficient of about 0.8), implying that the long-run effects of other explanatory variables are about fifth as large as their respective short-run effects, in case these variables change permanently.

Revenue-related variables - the log of real disposable income (in PPPs) and its growth rate have the expected positive sign (the terms of trade are also significant but surprisingly with a negative sign). The growth rate of the real disposable income has a material impact on saving with a one-standard deviation increase in this variable being associated to a rise of the household saving rate in the short run of 1.0 percentage point (based on regression (4)), representing the highest effect among the explanatory variables considered here.

Unreported regressions indicate that both positive and negative growth rates of real disposable income are positively related to saving rates (with coefficients statistically highly significant), suggesting that households increase their saving when disposable income grows faster but dissave as disposable income declines. This result is consistent with the hypothesis that households run down saving in the face of a negative income shock to smooth consumption. It is also in line with the observation in several European economies (e.g., Austria, Belgium, Greece, Italy, Spain) of a sharp decline in household saving rates in the wake of the GFC, despite higher economic uncertainty, in a context of falling disposable income.

The negative coefficient on the old dependency ratio is consistent with standard life-cycle models of consumption. A one-standard deviation increase in the old-age dependency ratio leads to a saving rate rise of 0.4 percentage points.

As expected, higher economic uncertainty, as proxied by unemployment, inflation, and GDP growth volatility, translates into larger saving rates, probably reflecting some precautionary saving motives. A one-standard deviation increase in GDP growth volatility is associated with an increase of the saving rate of 0.3 percentage points, and a one-standard deviation increase in inflation by 0.5 percentage points of the saving rate.

The real interest rate is positively related to the saving rate, suggesting that its substitution effects outweigh its income effects. This result contradicts Loayza et al.'s (2000) finding of a negative effect of the real interest rate on household saving but is consistent with Mody et al. (2012) whose sample of countries is closer to mine. 
Finally, the estimated coefficient of the change of the household debt-to-disposable income ratio (column (1)) is highly significant (under the $0.1 \%$ statistical level), with the expected negative sign. The economic impact of the variable is also important. A one-standard deviation increase in the change of the debt ratio - corresponding to 5 percentage points of gross disposable income - is associated with a 0.4 percentage point decline of the saving rate in the short run.

Table 4 - Saving rate and change in debt ratios, baseline

\begin{tabular}{|c|c|c|c|c|c|c|c|c|c|}
\hline & \multicolumn{9}{|c|}{ Dependent variable: Household gross saving rate } \\
\hline & $(1)$ & $(2)$ & (3) & $(4)$ & $(5)$ & $(6)$ & $(7)$ & $(8)$ & $(9)$ \\
\hline Lagged saving rate & $\begin{array}{l}0.811^{* * *} \\
(28.06)\end{array}$ & $\begin{array}{l}0.813^{* * *} \\
(28.88)\end{array}$ & $\begin{array}{c}0.820^{* * *} \\
(28.14)\end{array}$ & $\begin{array}{l}0.818^{* * *} \\
(30.01)\end{array}$ & $\begin{array}{c}0.820^{* * *} \\
(29.99)\end{array}$ & $\begin{array}{c}0.758^{* * *} \\
(14.98)\end{array}$ & $\begin{array}{c}1.111^{* * *} \\
(5.43)\end{array}$ & $\begin{array}{l}0.895^{* * *} \\
(13.22)\end{array}$ & $\begin{array}{c}0.952^{* * *} \\
(14.21)\end{array}$ \\
\hline Log (Real disposable income Yd) & $\begin{array}{c}3.421^{* * *} \\
(4.13)\end{array}$ & $\begin{array}{c}3.380^{* * * *} \\
(4.20)\end{array}$ & $\begin{array}{c}4.077^{* * * *} \\
(4.84)\end{array}$ & $\begin{array}{c}3.333^{* * *} \\
(4.64)\end{array}$ & $\begin{array}{c}3.213^{* * *} \\
(4.33)\end{array}$ & $\begin{array}{c}5.116^{* * *} \\
(3.19)\end{array}$ & & $\begin{array}{c}-0.562^{* *} \\
(-2.02)\end{array}$ & $\begin{array}{l}-0.338 \\
(-0.87)\end{array}$ \\
\hline Real growth rate of $\mathrm{Yd}$ & $\begin{array}{c}0.276^{* * *} \\
(8.43)\end{array}$ & $\begin{array}{c}0.276^{* * *} \\
(8.54)\end{array}$ & $\begin{array}{c}0.290^{* * *} \\
(10.69)\end{array}$ & $\begin{array}{c}0.346^{* * *} \\
(9.73)\end{array}$ & $\begin{array}{c}0.303^{* * *} \\
(6.09)\end{array}$ & $\begin{array}{c}0.400^{* * *} \\
(8.02)\end{array}$ & $\begin{array}{l}0.048 \\
(0.29)\end{array}$ & $\begin{array}{l}0.192 \\
(1.43)\end{array}$ & $\begin{array}{l}-0.041 \\
(-0.35)\end{array}$ \\
\hline Terms of trade $\mathrm{e}^{(\mathrm{a})}$ & $\begin{array}{l}-2.286^{*} \\
(-1.72)\end{array}$ & $\begin{array}{l}-2.428^{*} \\
(-1.90)\end{array}$ & $\begin{array}{l}-2.248 \\
(-1.49)\end{array}$ & $\begin{array}{c}-2.862^{* *} \\
(-2.33)\end{array}$ & $\begin{array}{c}-2.735^{* *} \\
(-2.33)\end{array}$ & $\begin{array}{l}-0.912 \\
(-0.22)\end{array}$ & & $\begin{array}{l}4.128 \\
(1.15)\end{array}$ & $\begin{array}{l}2.079 \\
(0.53)\end{array}$ \\
\hline Old dependency ratio & $\begin{array}{c}-0.075^{* *} \\
(-2.24)\end{array}$ & $\begin{array}{c}-0.078^{* *} \\
(-2.43)\end{array}$ & $\begin{array}{l}-0.045 \\
(-1.21)\end{array}$ & $\begin{array}{c}-0.074^{* *} \\
(-2.30)\end{array}$ & $\begin{array}{c}-0.069^{* *} \\
(-2.07)\end{array}$ & $\begin{array}{l}-0.155 \\
(-1.57)\end{array}$ & & $\begin{array}{l}-0.086 \\
(-1.55)\end{array}$ & $\begin{array}{l}-0.049 \\
(-0.95)\end{array}$ \\
\hline Young dependency ratio & $\begin{array}{l}0.013 \\
(0.32)\end{array}$ & $\begin{array}{l}0.011 \\
(0.26)\end{array}$ & $\begin{array}{l}-0.029 \\
(-0.59)\end{array}$ & $\begin{array}{l}0.005 \\
(0.14)\end{array}$ & $\begin{array}{l}0.012 \\
(0.33)\end{array}$ & $\begin{array}{l}-0.006 \\
(-0.08)\end{array}$ & & $\begin{array}{l}-0.046 \\
(-0.98)\end{array}$ & $\begin{array}{l}0.009 \\
(0.23)\end{array}$ \\
\hline Unemployment rate ${ }^{(a)}$ & $\begin{array}{c}0.627^{* *} \\
(2.12)\end{array}$ & $\begin{array}{c}0.594^{* *} \\
(2.09)\end{array}$ & $\begin{array}{c}0.803^{* * *} \\
(2.88)\end{array}$ & $\begin{array}{l}0.452 \\
(1.50)\end{array}$ & $\begin{array}{l}0.561^{*} \\
(1.91)\end{array}$ & $\begin{array}{l}0.440 \\
(1.22)\end{array}$ & & $\begin{array}{l}-0.395 \\
(-0.52)\end{array}$ & $\begin{array}{l}-1.297 \\
(-1.50)\end{array}$ \\
\hline Inflation rate ${ }^{(a)}$ & $\begin{array}{c}18.103^{* * *} \\
(5.31)\end{array}$ & $\begin{array}{c}18.448^{* * *} \\
(5.42)\end{array}$ & $\begin{array}{c}20.281^{* * *} \\
(5.15)\end{array}$ & $\begin{array}{c}17.020^{* * * *} \\
(5.52)\end{array}$ & $\begin{array}{c}12.570^{* * * *} \\
(3.30)\end{array}$ & $\begin{array}{c}24.986^{* *} \\
(2.76)\end{array}$ & & $\begin{array}{c}34.004^{* * *} \\
(3.40)\end{array}$ & $\begin{array}{c}21.117^{*} \\
(1.91)\end{array}$ \\
\hline GDP growth volatility & $\begin{array}{c}0.175^{* *} \\
(2.42)\end{array}$ & $\begin{array}{c}0.185^{* *} \\
(2.67)\end{array}$ & $\begin{array}{c}0.205^{* * *} \\
(2.73)\end{array}$ & $\begin{array}{c}0.181^{* * * *} \\
(3.08)\end{array}$ & $\begin{array}{c}0.185^{* * *} \\
(2.96)\end{array}$ & $\begin{array}{c}0.182^{* *} \\
(2.17)\end{array}$ & & $\begin{array}{l}0.283 \\
(1.50)\end{array}$ & $\begin{array}{l}0.203 \\
(0.90)\end{array}$ \\
\hline Real interest rate ${ }^{(a)}$ & $\begin{array}{c}17.790^{* * * *} \\
(4.43)\end{array}$ & $\begin{array}{c}17.734^{* * *} \\
(4.50)\end{array}$ & $\begin{array}{c}17.183^{* * * *} \\
(3.83)\end{array}$ & $\begin{array}{c}16.530^{* * * *} \\
(4.59)\end{array}$ & $\begin{array}{c}16.126^{* * *} \\
(4.38)\end{array}$ & $\begin{array}{c}25.497^{* * *} \\
(3.60)\end{array}$ & & $\begin{array}{l}-3.979 \\
(-0.42)\end{array}$ & $\begin{array}{c}-12.412 \\
(-0.88)\end{array}$ \\
\hline $\log ($ Debt/Yd) & $\begin{array}{l}0.259 \\
(1.23)\end{array}$ & $\begin{array}{l}0.370^{*} \\
(1.79)\end{array}$ & $\begin{array}{l}0.402 \\
(1.59)\end{array}$ & $\begin{array}{l}0.210 \\
(0.91)\end{array}$ & $\begin{array}{l}-0.106 \\
(-0.52)\end{array}$ & $\begin{array}{l}-0.982 \\
(-1.31)\end{array}$ & & $\begin{array}{c}1.652^{* *} \\
(2.17)\end{array}$ & $\begin{array}{l}0.561 \\
(0.72)\end{array}$ \\
\hline$\Delta(\mathrm{Debt} / \mathrm{Yd})$ & $\begin{array}{c}-0.087^{* * *} \\
(-4.11)\end{array}$ & & & & & & & & \\
\hline$\Delta(\mathrm{Debt} / \mathrm{Yd})>0$ & & $\begin{array}{c}-0.123^{* * *} \\
(-5.48)\end{array}$ & $\begin{array}{c}-0.115^{* * *} \\
(-4.39)\end{array}$ & $\begin{array}{c}-0.085^{* * *} \\
(-4.25)\end{array}$ & & $\begin{array}{c}-0.042^{* *} \\
(-2.10)\end{array}$ & $\begin{array}{l}-0.190 \\
(-1.12)\end{array}$ & $\begin{array}{l}-0.165^{*} \\
(-1.70)\end{array}$ & $\begin{array}{l}-0.026 \\
(-0.24)\end{array}$ \\
\hline$\Delta($ Debt $/ Y d)<0$ & & $\begin{array}{l}-0.032 \\
(-0.92)\end{array}$ & $\begin{array}{l}-0.035 \\
(-0.99)\end{array}$ & $\begin{array}{l}-0.027 \\
(-0.81)\end{array}$ & & $\begin{array}{l}-0.016 \\
(-0.41)\end{array}$ & $\begin{array}{l}0.500 \\
(0.71)\end{array}$ & $\begin{array}{l}0.341 \\
(1.13)\end{array}$ & $\begin{array}{l}0.333 \\
(1.21)\end{array}$ \\
\hline Change net financial wealth/Yd & & & $\begin{array}{l}-0.005 \\
(-1.61)\end{array}$ & & & & & & \\
\hline Real growth house prices & & & & $\begin{array}{c}-0.060^{* * *} \\
(-5.10)\end{array}$ & $\begin{array}{c}-0.062^{* * *} \\
(-4.96)\end{array}$ & $\begin{array}{c}-0.094^{* * *} \\
(-6.67)\end{array}$ & & $\begin{array}{l}-0.038 \\
(-0.69)\end{array}$ & $\begin{array}{l}-0.060 \\
(-0.98)\end{array}$ \\
\hline Real growth stock prices & & & & $\begin{array}{l}0.000 \\
(0.16)\end{array}$ & $\begin{array}{l}0.000 \\
(0.12)\end{array}$ & $\begin{array}{l}0.003 \\
(0.56)\end{array}$ & & & $\begin{array}{c}-0.024^{*} \\
(-1.78)\end{array}$ \\
\hline Credit effect $(\Delta \mathrm{Debt} / \mathrm{Yd})$ & & & & & $\begin{array}{c}-0.052^{* * *} \\
(-2.82)\end{array}$ & & & & \\
\hline Growth effect $(-\Delta Y \mathrm{~d} / \mathrm{Yd} \times$ Debt $/ \mathrm{Yd})$ & & & & & $\begin{array}{c}-0.122^{* * *} \\
(-2.74)\end{array}$ & & & & \\
\hline Country fixed effects & Yes & Yes & Yes & Yes & Yes & Yes & Yes & Yes & Yes \\
\hline Time fixed effects & Yes & Yes & Yes & Yes & Yes & Yes & Yes & No & No \\
\hline R-squared & 0.877 & 0.878 & 0.879 & 0.886 & 0.886 & 0.836 & - & - & - \\
\hline Number of observations & 1,059 & 1,059 & 931 & 1,038 & 1,038 & 356 & 955 & 1,040 & 1,038 \\
\hline Number of countries & 39 & 39 & 35 & 39 & 39 & 27 & 39 & 39 & 39 \\
\hline Number of instruments & - & - & - & - & - & - & 38 & 27 & 29 \\
\hline $\operatorname{AR}(2)$ test $p$-value & - & - & - & - & - & - & 0.566 & 0.671 & 0.885 \\
\hline Hansen test $p$-value & - & - & - & - & - & - & 0.505 & 0.511 & 0.606 \\
\hline
\end{tabular}

Columns (2) to (4) show estimates of the effects of positive versus negative changes in the debt-to-disposable income ratio. The two coefficients have the expected negative sign but differ widely in terms of statistical and economic significances. Only rising debt ratios are statistically significant at the conventional level (below $0.1 \%$ ), with a one-standard deviation increase in the change of the debt ratio $(+3.7$ percentage points $)$ being associated with a 
decline in the household saving ratio of 0.3 percentage points (based on regression (4)). In contrast, a decline in the debt ratio of a one-standard deviation ( -2.4 percentage points) is associated with statistically insignificant increase in the saving rate of only 0.06 percentage points.

Results are qualitatively similar when including control variables for wealth effects. In column (3), I report the impact from net financial wealth (scaled by disposable income). The coefficient of this variable is negative but not statistically significant. The change of the lagged net financial wealth is not significant neither (results not reported). Column (4) shows the effect from changes in house prices and stock market valuations. On theoretical grounds, the impact of house prices on saving from wealth effects is not clear-cut as an increase in house prices redistributes wealth within the household sector rather than boosting net aggregate wealth (IMF, 2008). The coefficients of both variables have the expected negative sign, consistent with a wealth effect explanation but the equity price variable is not statistically significant. A one-standard deviation increase (+7.1 p.p.) of the growth rate of real house prices leads to a 0.4 percentage point decline of the saving rate. ${ }^{25}$

Results on the impacts of positive and negative changes of the debt ratio are qualitatively similar when lagging the variables for house price growth and equity returns by one year. The growth rate of house prices is then not statistically significant anymore, contrary to equity returns which turn highly significant. Additional regressions (not reported) also indicate that both rising and declining real house price returns impact significantly the saving rate. A one-standard deviation shock on declining real house price returns (-3.4 p.p.) is associated with an increase of the saving rate of less than 0.3 percentage points.

Given that deleveraging is probably affecting real house prices (in a two-way relationship), one could infer that it indirectly increases saving rates. This effect seems, however, weak as the deleveraging variable is never significant, including when the real house price growth is dropped of the regression (column (2)). A possible explanation could be that the wealth effect from lower prices implied by deleveraging is compensated by a lower forced saving effect (lower down payment and repayments) for new borrowers when house prices are lower (see Balta and Ruscher, 2011).

The finding of the absence of impact of deleveraging also holds true when attempting to take into account Ricardian equivalence effects through the ratio of cyclically-adjusted government net lending to potential GDP (results not reported). The sample is then reduced to 30 countries due to limited coverage of this variable.

\footnotetext{
25 These results are in line with Case et al. (2005) who find for a panel of 14 OECD countries a larger effect on consumption of housing wealth than stock market wealth. More generally, the empirical literature on the relative sizes of the financial wealth and housing wealth effects reaches mixed results (see Cooper and Dynan, 2015, for a survey). As reminded by Pistaferri (2016), estimates of the housing wealth effect are typically small. A survey by the Congressional Budget Office (2007) states that "a \$1,000 increase in the price of a home this year will generate $\$ 20$ to $\$ 70$ of extra spending this year and in each subsequent year."
} 
In regression (5), I decompose the effect of the annual change of the debt-to-disposable income ratio into a net credit effect and a nominal income growth effect as follows:

$\Delta\left(\frac{D e b t}{Y^{d}}\right)_{t}=\frac{\Delta D e b t_{t}}{Y_{t}^{d}}-\frac{\Delta Y_{t}^{d}}{Y_{t-1}^{d}} \times \frac{D e b t_{t-1}}{Y_{t}^{d}}$.

The first term on the right-hand side - the net credit-to-disposable income ratio $\frac{\Delta D e b t_{t}}{Y^{d}}$ appears in the accounting identity (2) linking household saving to the change in financial liabilities (after dividing all terms of the identity by household disposable income) and is therefore expected to be an important driver of saving rates. ${ }^{26}$ The second term on the righthand side - the nominal income growth effect $\frac{\Delta Y^{d} t}{Y^{d} t_{-1}} \times \frac{D e b t_{t-1}}{Y^{d} t}-$ also matters for the analysis of the effect of deleveraging on saving, given that several episodes of household deleveraging occur through credit growth lagging behind income growth as seen in Section 2 .

Results show that both coefficients are statistically highly significant, suggesting that household saving decisions are influenced by changes in debt ratios whether these latter are driven by changes in the absolute or in the relative level of credit. Additional regressions (results not reported) however indicate that nor active deleveraging (the net borrowing effect), nor passive deleveraging (the nominal income growth effect) are significant. In contrast, both active and passive debt buildups are significantly related to saving rates. ${ }^{27}$

Results presented so far indicate that rising indebtedness is associated with lower saving rates, but that declining debt ratios are not correlated with saving, contrary to the consensus view that deleveraging translates into larger saving ratios. This asymmetric effect of credit may reflect a number of factors. ${ }^{28}$ First, saving rates may decline with rising indebtedness because of a financial-deepening effect and apart from this structural effect, the response of saving to credit could be relatively weak. Second, the response of saving rates to declining debt could be highly heterogeneous across economies, implying large standard errors of panel estimates of the coefficient of declining debt ratios. Finally, some observations with declining debt ratios, for example in years of very high income growth, could represent noisy observations, without any relation to deleveraging phases.

Regression (6) addresses this latter issue by restricting the estimation sample to observations with a full boom and bust cycle of the debt-to-income ratio as reported in Tables 1 and 2.

\footnotetext{
${ }^{26}$ Previous analyses of the determinants of household saving rates use a similar ratio of credit flow to GDP or to disposable income as a proxy of financial depth (e.g., Lyoza et al., 2000 or Mody et al., 2012). One notable difference of these studies compared with the present paper is that they consider a broad measure of credit to the non-financial private sector, instead of credit to households.

${ }^{27}$ The significant negative coefficient on the nominal growth effect during debt buildups implies a higher saving rate as nominal growth gets larger and probably captures the uncertainty effect from inflation.

${ }^{28}$ Note that the asymmetry mentioned here refers to the difference in the statistical significances of leveraging and deleveraging, not to the size of the estimated coefficients of the two variables, as would be informed by a Wald test of equality, in case coefficients of the two variables were significantly different from zero.
} 
More specifically, for each deleveraging episode, the estimation period starts five years before the deleveraging and ends the year the debt ratio reaches a trough (Table 1) or 2019 in the case of on-going deleveraging episodes (Table 2). In this way, I focus on the evolution of saving during the boom and the bust of household debt, limiting the possible influence of any noisy observations. ${ }^{29}$ As shown in column (6), the change in the debt ratio remains significantly related to the saving rate during debt build-ups but not in deleveraging years. Focusing on observations covering exclusively boom and bust periods of debt therefore confirms the asymmetric effect of the change in the debt ratio on saving.

Columns (7) to (9) report results for the whole sample of observations using the system GMM estimator. ${ }^{30}$ Regression (7) includes year fixed effects but given the constrains on the number of instruments, only a sub-set of controls can be considered in the regression. None of the variables are however significant. In regressions (8) and (9), a common time trend replaces the year fixed effects, allowing to include the whole set of control variables. ${ }^{31}$ Again, the coefficient on the deleveraging variable is not significant and is even positive while the debt build-up variable has a negative coefficient statistically significant at 10 percent in regression (8). In alternative regressions where the house price growth and the equity returns are lagged by one year (results not reported), the debt build-up variable is highly significant in both regressions while the coefficient of the deleveraging variable remains positive and even turns significant at 10 percent in one regression. In any cases, deleveraging is never associated with higher saving rates.

\section{First-differenced saving rates}

To address possible non-stationarity issues, and given the long time span of the analysis, I also estimate regressions where the saving rate and most control variables are first differenced:

$$
\begin{aligned}
& \Delta s_{i, t}=\alpha_{0} \Delta s_{i, t-1}+\alpha_{1} \Delta \ln R Y_{i, t}^{d}+\alpha_{2} \Delta G R Y_{i, t}^{d}+\alpha_{3} \Delta \text { Trade }_{i, t}+\alpha_{4} \Delta \text { Old }_{i, t}+\alpha_{5} \Delta \text { Young }_{i, t} \\
& +\alpha_{6} \Delta U N R_{i, t}+\alpha_{7} \Delta \text { Inflation }_{i, t}+\alpha_{8} \Delta \text { Volatility }_{i, t}+\alpha_{9} \Delta I R S_{i, t}+\alpha_{10} \ln \left(\frac{\text { Debt }}{Y^{d}}\right)_{i, t} \\
& +\alpha_{11} \Delta\left(\frac{D e b t}{Y^{d}}\right)_{i, t}+\eta_{i}+\gamma_{t}+\varepsilon_{i, t} .
\end{aligned}
$$

\footnotetext{
${ }^{29}$ The deleveraging episodes of the Netherlands and of Switzerland in the early 1990s, as well as the one of South Africa at end 1990s-early 2000s are not included in the estimations because of a lack of data. The episode of Greece of early 2010s is excluded as the debt ratio increased in 2011-2013 due to a drop of disposable income and despite the contraction of the stock of debt, making the change of the debt to disposable income ratio irrelevant.

30 The Arellano-Bond test indicate that serial correlation in the residuals, potentially undermining the use of lagged variables as instruments, should not be a concern. The Hansen test of over-identifying restrictions does not suggest that any instruments might be invalid.

${ }^{31}$ The GARCH-based measure of GDP growth volatility is replaced by the standard deviation of quarterly real GDP growth measured over the two preceding years. In the GMM approach, explanatory variables are instrumented by their lagged values which is not possible with the GARCH-based variable as its construction uses both past and future information.
} 
Results presented in Appendix Table 2 are qualitatively similar as for regressions of the saving rate in level, although the lagged dependent variable is not significant anymore given the absence of persistence of the change of the saving ratio.

\section{Consumption growth}

Finally, as an additional robustness check of the results, I investigate the effect of deleveraging on consumption growth by running the following regression:

$$
\begin{aligned}
& \left(\frac{\Delta \text { Conso }}{\text { Conso }}\right)_{i, t}=\alpha_{0}\left(\frac{\Delta \text { Conso }}{\text { Conso }}\right)_{i, t-1}+\alpha_{1} \Delta \ln R Y_{i, t}^{d}+\alpha_{2} \Delta G R Y_{i, t}^{d}+\alpha_{3} \Delta \text { Trade }_{i, t}+\alpha_{4} \Delta \text { Old }_{i, t} \\
& +\alpha_{5} \Delta \text { Young }_{i, t}+\alpha_{6} \Delta U N R_{i, t}+\alpha_{7} \Delta \text { Inflation }_{i, t}+\alpha_{8} \Delta \text { Volatility }_{i, t}+\alpha_{9} \Delta I R S_{i, t} \\
& +\alpha_{10} \ln \left(\frac{D e b t}{Y^{d}}\right)_{i, t}+\alpha_{11} \Delta\left(\frac{D e b t}{Y^{d}}\right)_{i, t}+\eta_{i}+\gamma_{t}+\varepsilon_{i, t} .
\end{aligned}
$$

Results presented in Appendix Table 3 confirm that rising indebtedness is associated with higher consumption growth, but that deleveraging does not weigh on consumption.

Overall, estimates suggest the absence of any effect on saving rates or consumption growth from declining household debt ratios for the average economy, even when limiting the estimation sample to observations covering exclusively boom-bust credit cycles. While the effect from rising debt ratios is robust to various specifications and control variables, the impact from declining debt ratios appears non-significant, lending support to the hypothesis of an asymmetric effect of changes of debt ratios on saving and consumption.

Mortgage market liberalization - in particular the increased availability of refinancing opportunities and lower effective down payment requirements - may partly account for this asymmetry, as household indebtedness rarely returns to its pre-boom level and reversals of financial reforms are scares (Abiad et al., 2010). Household debt defaults could also explain why for a given change of the debt ratio, the economic impact on saving rates of rising indebtedness is significant contrary to the effect from deleveraging. While households may take advantage of looser credit conditions to finance consumption during the boom, defaulting on debt during the bust could mitigate the negative effect from lower credit and makes consumption smoother. Finally, cross-country heterogeneity in the credit-saving relationship could also account for the large standard errors of the estimated coefficient of declining debt ratios, as examined in the next section.

\section{B. Cross-Country Heterogeneity and the Role of Credit Market Institutions}

Although panel data estimates indicate the absence of a significant effect of deleveraging on saving rates and consumption growth, this finding may not be true for all economies given the cross-country heterogeneity in credit market institutions and other country-specific institutional settings (Table 3) possibly shaping the response of household saving to credit. Scatter plots between quarterly net credit-to-disposable income ratios and household saving rates over 1995-2019 indeed suggest that the strength of the credit-saving relationship varies 
greatly across countries (Figure 3). The saving-credit correlation is, for example, particularly strong in Australia, Canada, Korea, Russia, the United Kingdom, or the United States while it appears virtually nil in some other countries (e.g., Belgium, Finland, Italy, Poland). ${ }^{32}$ Against this background, this section investigates the role played by credit market features and other institutional settings in explaining cross-country differences in the credit-saving relationship.

Following the discussion of Section III, I consider four interaction variables with the change of debt ratios: (i) the prevalence of consumer credit as a share of disposable income (dummy variable equal to one if the average ratio of consumer credit to disposable income is larger than 14 percent; zero otherwise); ${ }^{33}$ (ii) the availability of housing equity withdrawal (HEW); (iii) the importance of homeownership (dummy variable equal to one if the average homeownership rate of the country is above the sample median); and (iv) the level of the saving rate in conjunction with the share of pension funds in the economy (dummy variable equal to one if the country has an average saving rate below sample median and a share of pension funds in GDP above sample median; zero otherwise).$^{34}$ I do not consider the interaction with the degree of lender recourse, given limited cross-country variation of this variable.

Figure 3 - Net credit-to-disposable income ratios $\frac{\Delta D e b t}{Y^{d}}$ $(x$-axis, percentage points) and saving rates $(y$-axis, per cent).

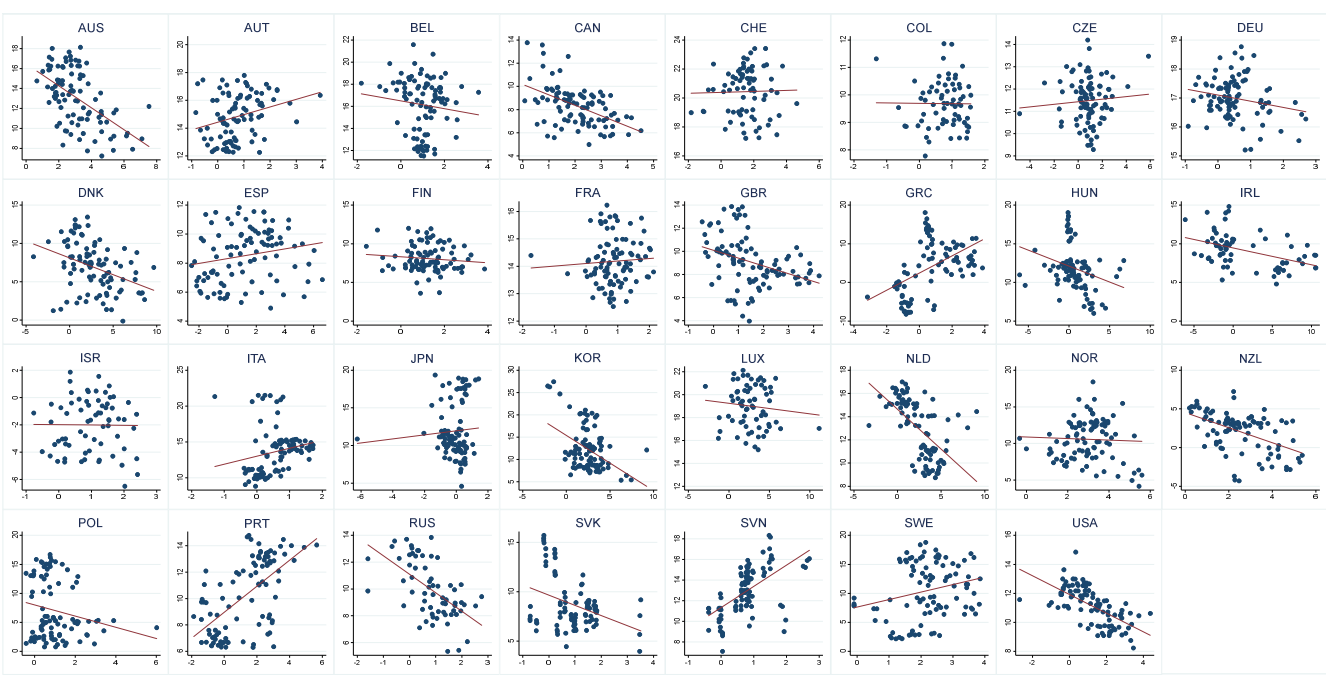

Sources: OECD, national accounts, BIS.

\footnotetext{
32 The correlations between saving rates and the changes in debt ratios are pretty similar.

33 The 14-percent threshold allows to isolate countries with an average credit ratio above the sample median (12 percent) during several years surrounding any deleveraging episode (Australia, Canada, Chile, China, Greece, Hungary, Ireland, Israel, Korea, Russia, South Africa, United Kingdom, and United States).

${ }^{34}$ Information on institutional settings is in most cases only available over the past 20 years so the analysis might be carried out from the early 2000s rather than over the whole sample period. The ranking of countries with respect to most institutional factors and credit-market features is however unlikely to have changed much over time. Results are anyway qualitatively similar when regressions are estimated from 2000 rather than over the whole sample period.
} 
Table 5 reports results of the regressions of the saving rate. As in the baseline regressions, rising debt ratios are significantly associated with lower saving rates for the average economy.

Table 5 - Saving rate and interaction effects of institutional settings with change of debt ratios

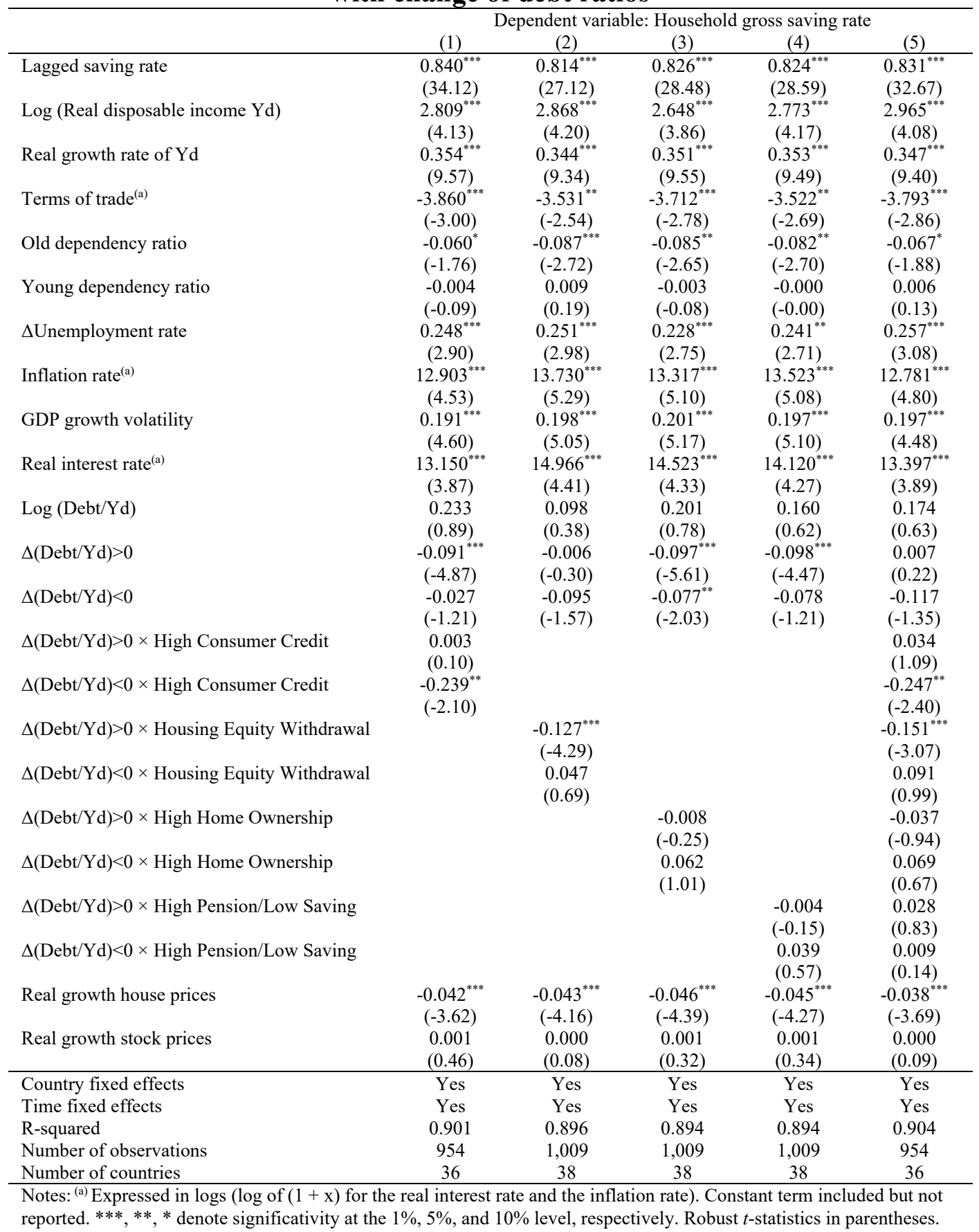

Importantly, the estimated coefficient on the interaction between the "High Consumer Credit" dummy and the negative change of the debt ratio is also significantly negative, at the 5-percent level (column (1)), indicating that deleveraging is associated with higher saving 
rates in countries where consumer credit is widespread but does not have any effect on saving in other countries.

Regressions (2) to (5) explore the role of other structural factors in shaping the credit-saving relationship. The presence of HEW seems to matter but only during debt buildups. There is no evidence that countries where HEW is available experience an increase in their saving rates during deleveraging (column (2)). Finally, nor homeownership, nor pension funds combined with the level of saving rates (a proxy for available liquid saving) seem to affect the saving-credit relationship, whether during debt buildups or during deleveraging (columns (3) and (4)).

These findings also hold true when the interaction effects are considered all together (column (5)). Based on estimates of regression (5), the saving rate is increasing by almost 0.3 percentage points following a one-standard deviation increase in the deleveraging variable in high consumer credit countries (-1.04 percentage points) while the most meaningful economic impact remains from the growth of real disposable income $(+1$ percentage point for a one-standard deviation increase). The economic impact of deleveraging is even smaller once excluding from the estimation sample Korea, which belongs to the high consumer credit group of countries and experienced two deleveraging episodes over 1997-2003 with a significant rise in the saving rate and a dip in consumption. ${ }^{35}$

Regressions of the change of the saving rate (Appendix Table 4) confirm the role of consumer credit in shaping the credit-saving during the deleveraging. The change of the saving rate as the debt ratio declines is significantly positive in countries with a relatively large share of consumer credit in disposable income, while in other countries, deleveraging and the change of the saving rate are not related (columns (1) and (5)). Again, there is some evidence that the availability of HEW strengthens the relationship between the change in saving and debt buildups but not with debt ratio decreases (columns (2) and (5)), while home ownership and the availability of liquid saving do not play any role in the credit-saving relationship (columns (3) to (5)).

Finally, results are qualitatively similar as regards consumption growth (Appendix Table 5): deleveraging is negatively associated with consumption growth but only in countries where consumer credit is prevalent. The interaction effect is statistically significant at less than 0.1 percent and economically meaningful. In contrast, there is no evidence that other structural factors are influencing the deleveraging-consumption relationship (columns (2) to (5)). HEW and home ownership matter for the credit-saving relationship but only during debt buildups, and with interaction effects being significant at only 10 percent.

\footnotetext{
${ }^{35}$ Korea experienced a contraction of real consumption of 13 percent in 1998 while the debt ratio decreased by more than 12 percentage points. Likewise, the 2003-04 deleveraging was accompanied by a contraction of consumption as the country saw distressed credit card debt rising from 7.5 percent of total credit card receivables in 2000 to 34 percent in 2003 while household delinquencies reached at the end of 2003 about 17 percent of the economically active population, triggering a contraction of GDP in the first half of the year (He et al., 2005).
} 
The finding that consumption growth is not affected by deleveraging in countries with HEW and is only weakly impacted in debt buildups is not surprising given mixed evidence in the literature on the effect of HEW on consumption, with several studies showing a relatively modest short-term impact of changes in housing equity withdrawal on consumption growth (e.g. Smith, 2006 for New Zealand). ${ }^{36}$ Results are also consistent with studies reporting that only a small share of HEW is used for consumption. Survey evidence for Australia, the Netherlands, or the United Kingdom (Ebner, 2013) suggests for instance that HEW is not used to finance consumption but mostly to pay off old debt or to make home improvements while in the U.S., only 16 percent of HEW was devoted to consumption in 2001-2002, the rest being allocated among home improvements (that is residential investment), repayment of debt, and acquisition of real assets (Menegatti and Roubini, 2007). ${ }^{37}$

Estimates therefore lend support to the hypothesis that the presence of consumer credit in the economy plays a significant role in the transmission of credit to saving rates, contrary to mortgages, since only countries where consumer credit is prevalent show a statistically significant relationship between deleveraging and saving rates or consumption growth. The next section further tests the relevance of this hypothesis by looking at the effects of changes of consumer debt-to-income ratios and of changes of mortgage debt-to-income ratios on saving rates and on consumption growth.

\section{Consumer versus Mortgage Debt Ratios}

An alternative approach to test for the importance of consumer credit in driving the creditsaving relationship during deleveraging is to differentiate the effects on saving of consumer credit and of mortgages. Long time series (at least 25 years) of consumer debt and of mortgages are available for only a limited number of countries of the sample (Australia, Belgium, Canada, France, Greece, United Kingdom, United States) and several deleveraging episodes of the 1980s, in particular those of the Nordic countries, are not covered. Data however cover the recent boom-bust episodes surrounding the GFC, as information on consumer credit and mortgages is available since at least the mid-2000s.

A limitation of this approach is that flow-of-funds data, which provide complete information on loans from both monetary and financial institutions (MFIs) and from other institutions, are available for only a subset of countries. In several cases, information comes from the balance sheets of MFIs only, offering a partial coverage of credit volumes, especially for recent years

\footnotetext{
${ }^{36}$ Klyuev and Mills (2007) argue for instance that the fall in the U.S. saving rate in the run-up to the GFC cannot be attributed to HEW but mainly to housing wealth effects. Financial liberalization has increased the liquidity of home equity by making its withdrawal easier but HEW itself does not explain changes in saving rates. Likewise, Benito et al. (2006) document that the relationship between HEW and consumption in the United Kingdom has weakened in the beginning of the years 2000 as agents benefited from greater access to unsecured credit during the 1990s. In contrast, Bailliu et al. (2012) report a significant effect of HEW on consumption in Canada based on micro data, estimating an average share of home-equity extraction used to finance consumption and home renovation of about 40 percent.

${ }^{37}$ In contrast, using household-level data over 2002-2006, Mian and Sufi (2011b) find little evidence that home equity-based borrowing in the United States is used to pay down credit card balances, to purchase new homes or investment properties. While these authors do not have data on real outlays, they conclude that consumption and home improvement are possible uses of the increased borrowing in response to rising house prices.
} 
given the rising role of the non-banking financial sector in the provision of credit to households. For this reason, results should be interpreted with caution.

Figure 4 - Contributions of changes of consumer and of mortgage debt ratios to debt booms and deleveraging in selected countries (percentage points of disposable income)
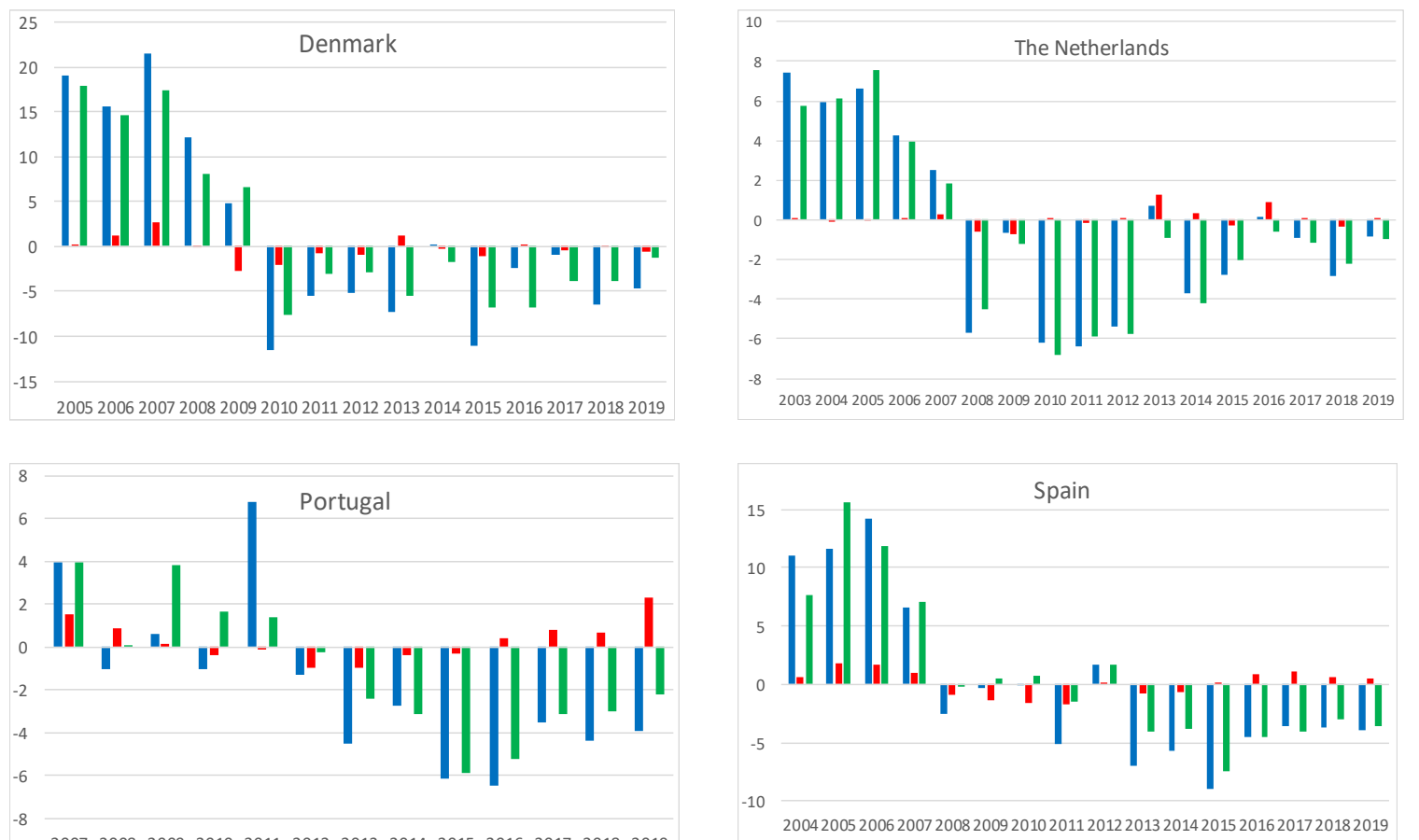

2007200820092010201120122013201420152016201720182019

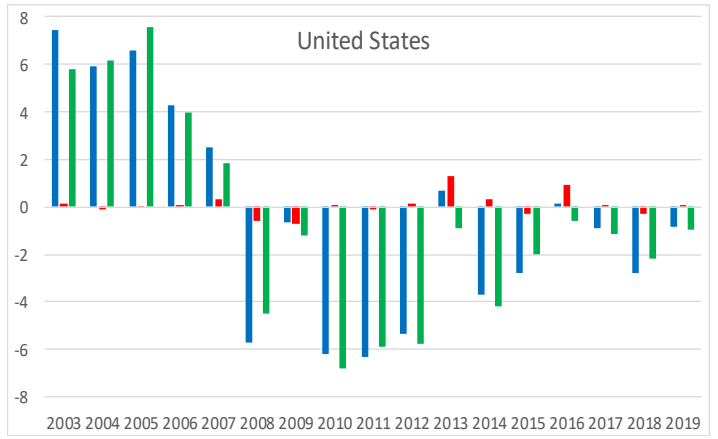

- Aggregate debt

- Consumer credit

- Mortgages

Sources: OECD, national central banks, and author's calculations.

Note: the difference between the change of the aggregate amount of debt and the sum of the changes of consumer credit and of mortgages can reflect the fact that: (i) aggregate debt relates to credit extended by MFIs and other financial institutions, while for some countries, consumer debt and mortgages data refer to credit extended by MFIs only; and (ii) the aggregate amount of debt applies to the aggregate account of households and non-profit institutions serving households (NPISHs), contrary to consumer credit and mortgages data which apply only to households.

It is worth noting that mortgage debt generally accounts for the lion's share of household debt. Even in countries where consumer credit is prevalent, household deleveraging is largely driven by mortgage deleveraging, while the contribution from declining consumer debt ratios 
tends to be marginal, except when the country experienced a consumer credit boom before the deleveraging. For example, during the deleveraging episodes observed in the wake of the GFC, contractions of the consumer credit-to-income ratios have represented only a small fraction of the annual decrease of household aggerate debt ratios, including in the "highconsumer credit" countries like the United Kingdom or the United States, where the deleveraging has been mainly explained by declines in mortgage debt ratios (Figure 4). Although ratios of consumer debt to disposable income tend to decline in the early phase of the deleveraging, they often increase in subsequent years, as economic activity picks up, while mortgage and aggregate debt ratios are still contracting for several years (e.g., in Portugal, Spain, United States).

Table 6 reports results of estimations of the separate impacts of changes in consumer credit and mortgage debt ratios on the saving rate. In column (1), I estimate the baseline regression for the restricted sample of observations with available data for the series of consumer credit and mortgages. Results are qualitatively similar as for the full sample (Table 4), with the effect of the change of the debt-to-income ratio on saving being asymmetric.

Decomposing positive and negative changes of the debt ratios between consumer credit and mortgages shows a statistically significant relationship between consumer credit deleveraging and saving, in both LSDV (column (2)) and system GMM regressions (column (3)), but no significant relationship between decreasing mortgage debt ratios and saving rates. The change of the mortgage debt ratio is negatively associated with saving, but only during debt buildups.

Results therefore support the hypothesis that consumer credit, and not mortgages, is driving the relationship between saving and deleveraging in some countries. The saving rate is increasing by almost 0.2 percentage points following a one-standard deviation increase in the consumer credit deleveraging variable ( -0.57 percentage points) according to LSDV regression and by 3 times more based on GMM estimates (column (3)). In contrast to the debt overhang effect, which affects spending through the debt service burden whether this latter concerns consumer credit or mortgages, the impact of deleveraging on saving therefore varies depending on the nature of credit.

Regressions for the change of the saving ratio (Appendix Table 6) and for consumption growth (Appendix Table 7) provide a similar finding. Declining mortgage debt ratios are never associated with larger changes of saving rates or lower consumption growth rates.

The consumer credit-saving relationship could reflect reverse causality, ${ }^{38}$ as deleveraging episodes tend to take place in a subdued demand environment. Still, bi-directional causation between consumer credit and consumption during deleveraging cannot be excluded, insofar as deleveraging and the associated reduction in consumer borrowings result from credit tightening by banks. For instance, Gropp et al. (2019) provide evidence for the U.S.

\footnotetext{
${ }^{38}$ Although the relationship is also significant in system GMM regressions, whose objective is precisely to address endogeneity issues.
} 
deleveraging in the wake of the GFC that the reduction in non-mortgage and credit card borrowing was more driven by cutbacks in the provision of credit by banks than by a demand-based response to lower housing wealth. During deleveraging, banks tighten credit conditions, including for consumer credit with some direct implications for consumption of liquidity-constrained households. In this context, the macroeconomic impact of deleveraging on consumption crucially depends on the importance of consumer credit in the economy.

Table 6 - Saving rate, consumer credit, and mortgages

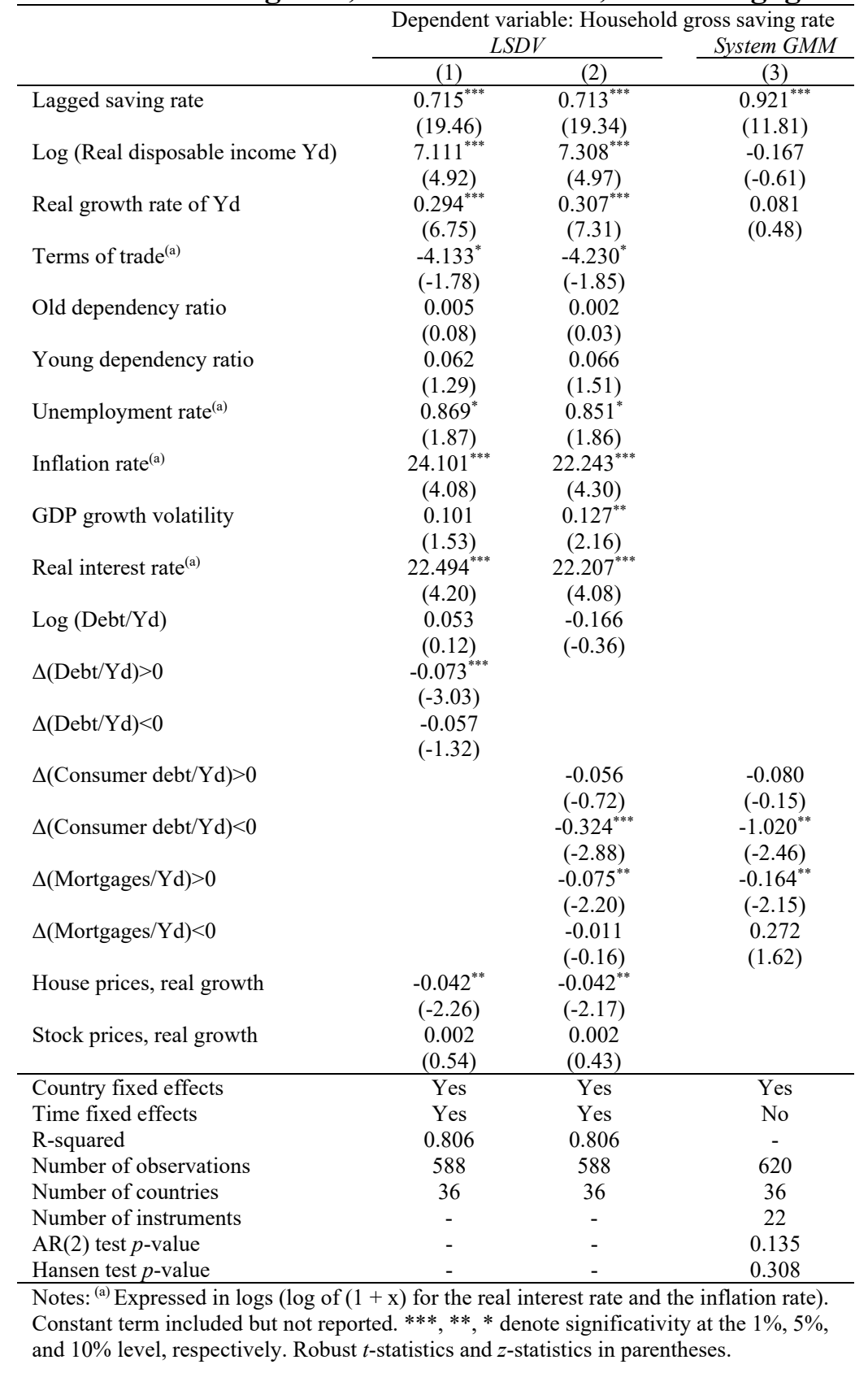

Overall, results indicate that household deleveraging episodes are mainly driven by decreasing mortgage debt-to-income ratios and that they are not weighing on consumption growth, in line with the observation of Dossche et al. (2018) for the euro area that "in 
contrast to the period before the crisis, steady euro area consumption growth has been coupled with a gradual decrease in household indebtedness (...)". In countries where consumer credit is prevalent and deleveraging can be accompanied by decreasing consumer debt ratios, household deleveraging could still be associated with higher saving rates in the early phase of the debt adjustment.

\section{Conclusion}

This paper finds that household deleveraging does not increase saving rates or reduce consumption growth, contrary to what is argued by several policy makers and theoretical papers. Although declining indebtedness can be associated with higher saving rates or with lower consumption growth in some countries, this relationship reflects a contraction in consumer credit - which represents only a small portion of total household debt - while a decrease in the mortgage debt-to-income ratio is never associated with higher saving rates or with lower consumption growth. This suggests that a policy containing household debt through lower mortgages would not necessarily be harmful for consumption.

Although the adjustment of the saving rate could be significant in countries where consumer credit is relatively important, it could be short-lived, insofar as the credit boom relates mainly to mortgages. ${ }^{39}$ Evidence for the United States (Vidangos, 2015) indicates for instance that in the initial stage of the deleveraging which started in 2008, both mortgages and consumer credit were negatively impacted, but that from 2010, the deleveraging concerned exclusively mortgages - while consumer credit increased at a robust pace for several years - in line with the idea that credit stress initially affects all types of credit segments but that later on, the deleveraging applies only to the credit segment that experienced a boom before the crisis.

Other channels associated with household deleveraging and not present in historical data could also weigh on consumption future debt adjustment. In particular, in countries where interest-only mortgages sharply expanded in the run-up to the GFC, public authorities may be tempted to modify the redemption profile of loans to reduce the risk exposure of banks and accelerate the deleveraging process. ${ }^{40}$ Bringing forward the repayment of principal of interest-only loans in the context of a renegotiation of the contracts or imposing regular amortising requirements for all new mortgages would mechanically translate into higher saving rates. Likewise, in countries with flexible mortgage rates, a rise in interest rates would reduce new borrowings and contribute to the deleveraging process but also increase the debt

\footnotetext{
${ }^{39}$ Deleveraging in Canada has not yet started but the country experienced a dip in non-mortgage credit to households in 2008-09, when several banks faced funding difficulties on the U.S. money market. As evidenced by Damar et al. (2014), this tightening however did not translate into lower levels of consumption as the credit shock was temporary and most households compensated by drawing down liquid assets to smooth consumption. In the context of a more prolonged adverse lending shock - as is typically the case during a deleveraging phase - consumption would probably react more negatively.

${ }^{40}$ In the Netherlands, for instance, interest-only loans (encouraged by unlimited tax deduction on interests until 2013) represented more than 50 percent of total mortgages in the wake of the GFC, making the deleveraging process particularly slow in the early years of the adjustment.
} 
payment ratio to the detriment of consumption. This latter channel could be particularly harmful in economies where bankruptcy laws are not debtor-friendly, as currently the case in most countries. ${ }^{41}$

At least two policy options could be considered to contain risks of a debt overhang and improve the resilience of households. First, policies reducing the costs for households to default on their debt (permanently, and not only during crises), as implemented by the United States in the wake of the Great Depression, would speed up deleveraging and limit the duration of the debt overhang on consumption. As found by Auclert et al. (2019), in the wake of the GFC, U.S. states with more generous bankruptcy exemptions showed significantly smaller declines in local non-tradable employment and larger increases in consumer debt write-downs compared to the states with less generous exemptions. ${ }^{42}$

Second, macro-prudential policy may aim at containing household debt developments, and not only at improving the quality of credit (as often reflected by households' debt servicing capacity and the instantaneous probability of default), in order to limit risks of a debt overhang. Experience of the last decade indicates that the macroprudential framework in several countries could not prevent a further buildup of household debt in a context of massive liquidity injection by central banks.

\footnotetext{
${ }^{41}$ As noted by Jordà et al. (2020), the lack of debtor-friendly arrangements in the household sector is one of the reasons why household debt overhang is found empirically to be more harmful for economic growth than the debt overhang of non-financial corporates, for which restructuring or liquidation arrangements are more common.

${ }^{42}$ An increase in personal bankruptcy protection is likely to boost demand and simultaneously reduce supply of credit and raise interest rates. Empirical evidence for the United States (Severino and Brown, 2020) suggests that the net effect is positive for unsecured credit holdings (primarily credit card debt) and neutral for secured debt (mortgage and auto loans).
} 


\section{Appendix Figure 1 - Household debt-to-disposable income ratios (in percent)}
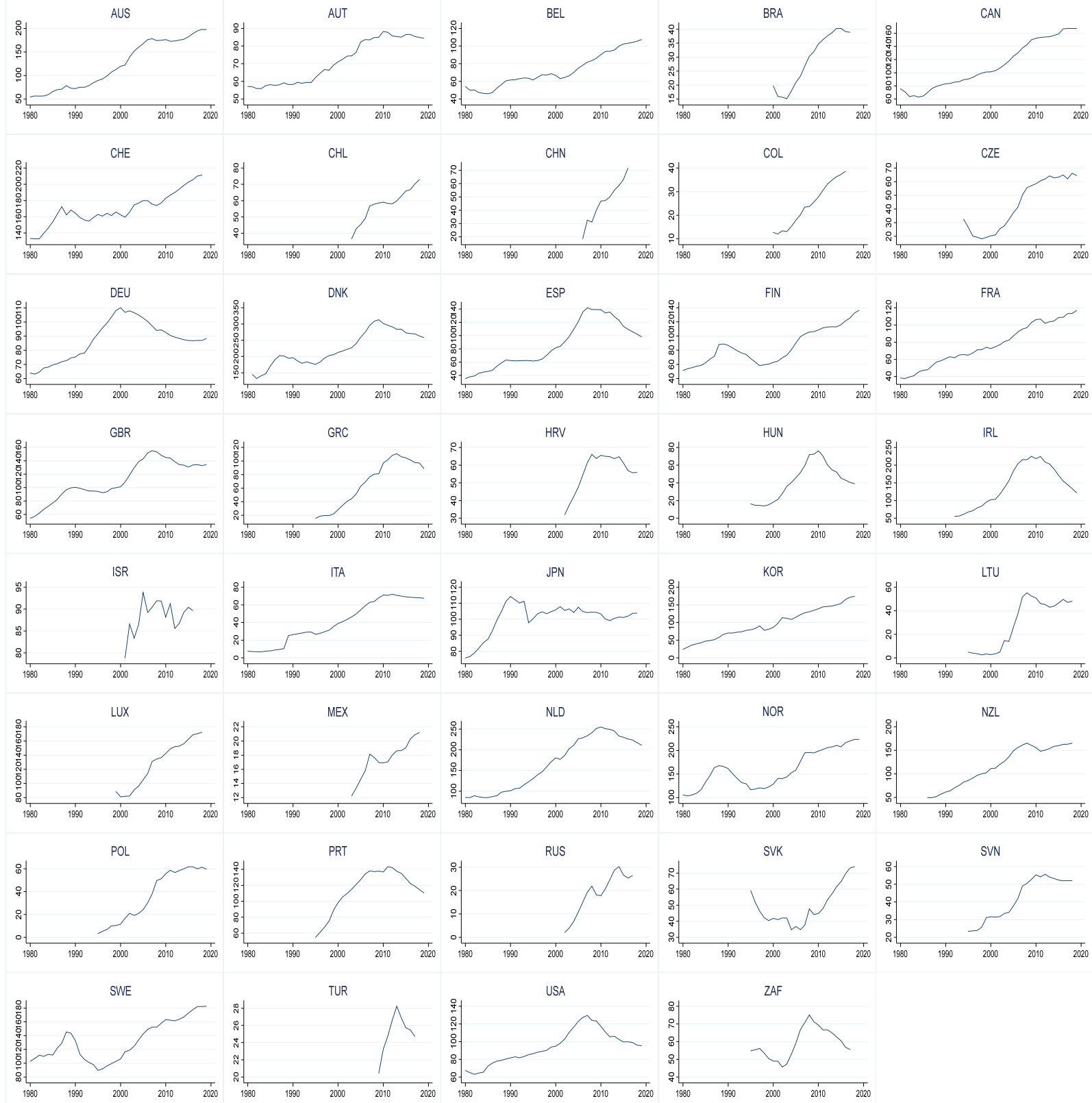

Sources: OECD, national accounts, BIS. 


\section{Appendix Table 1 - Variable definitions and data sources}

\begin{tabular}{|c|c|c|}
\hline Variable & Definition & Sources \\
\hline Saving rate (and disposable income) & $\begin{array}{l}\text { Ratio of household gross saving to gross } \\
\text { disposable income. }\end{array}$ & $\begin{array}{l}\text { OECD National Accounts Statistics, OECD } \\
\text { through Datastream (Brazil), Eurostat (Croatia), } \\
\text { OECD net saving rate for Chile } \\
\text { (https://data.oecd.org/hha/household- } \\
\text { savings.htm). }\end{array}$ \\
\hline Gross disposable income & Household gross disposable income & $\begin{array}{l}\text { OECD National Accounts Statistics, OECD } \\
\text { through Datastream (Brazil, China), Eurostat } \\
\text { (Croatia). }\end{array}$ \\
\hline Consumption growth & $\begin{array}{l}\text { Growth of private final consumption } \\
\text { expenditure of households deflated by } \\
\text { CPI. }\end{array}$ & $\begin{array}{l}\text { OECD National Accounts Statistics, National } \\
\text { statistics institutes (China, Croatia). }\end{array}$ \\
\hline Household debt & $\begin{array}{l}\text { Annual data: Total financial liabilities of } \\
\text { households. } \\
\text { Quarterly data: debt (loans) of } \\
\text { households. }\end{array}$ & $\begin{array}{l}\text { OECD National Accounts Statistics (see Bouis } \\
\text { et al., } 2013 \text { for details); BIS credit to } \\
\text { households and NPISHs from all sectors at } \\
\text { market value, domestic currency, adjusted for } \\
\text { breaks (Brazil, China, Colombia, Mexico, } \\
\text { Russia, Turkey), Eurostat (Croatia, Lithuania), } \\
\text { national central bank (New Zealand - extended } \\
\text { after } 2013 \text { using BIS growth rate; South } \\
\text { Africa). BIS for quarterly series. }\end{array}$ \\
\hline Real disposable income & $\begin{array}{l}\text { Household disposable income deflated by } \\
\text { the Consumer Price Index (CPI) and } \\
\text { converted in US dollars using PPPs. }\end{array}$ & $\begin{array}{l}\text { OECD National Accounts Statistics, Eurostat } \\
\text { and World Development Indicators (WDI) } \\
\text { (Brazil, Croatia). }\end{array}$ \\
\hline Terms of trade & Ratio of export and import prices. & OECD National Accounts Statistics, WDI. \\
\hline Old and young-age dependency ratios & $\begin{array}{l}\text { Proportions of the population aged } 65 \\
\text { and above, and of the population aged } \\
\text { below } 15 \text { in the working age population } \\
\text { (population aged 15-64), respectively. }\end{array}$ & WDI. \\
\hline Unemployment rate & $\begin{array}{l}\text { Unemployed persons as a percentage of } \\
\text { the labour force. }\end{array}$ & $\begin{array}{l}\text { OECD National Accounts Statistics, WDI } \\
\text { (Brazil, Croatia, Russia, South Africa). }\end{array}$ \\
\hline Inflation rate & Growth rate of the CPI. & OECD National Accounts Statistics, WDI. \\
\hline GDP growth volatility & $\begin{array}{l}\text { GARCH }(1,1) \text { measure of real GDP per } \\
\text { capita growth volatility. }\end{array}$ & $\begin{array}{l}\text { OECD National Accounts Statistics, Eurostat } \\
\text { and IMF (Croatia), and author's calculations. }\end{array}$ \\
\hline GDP growth standard deviation & $\begin{array}{l}\text { Annual standard deviation of quarterly } \\
\text { real GDP per capita growth. }\end{array}$ & $\begin{array}{l}\text { OECD National Accounts Statistics, Eurostat } \\
\text { and IMF (Croatia), and author's calculations. }\end{array}$ \\
\hline Real short-term interest rate & $\begin{array}{l}\text { Real three-month interest rate based on } \\
\text { private consumption deflator. }\end{array}$ & $\begin{array}{l}\text { OECD National Accounts Statistics; } \\
\text { Datastream (China, Croatia, Turkey). }\end{array}$ \\
\hline $\begin{array}{l}\text { Household net financial wealth-to-disposable } \\
\text { income ratio }\end{array}$ & $\begin{array}{l}\text { Household financial assets minus } \\
\text { liabilities, divided by gross disposable } \\
\text { income. }\end{array}$ & $\begin{array}{l}\text { OECD National Accounts Statistics, national } \\
\text { central banks (Russia), Eurostat (Croatia, } \\
\text { Turkey), and author's calculations. }\end{array}$ \\
\hline Real house price growth rate & $\begin{array}{l}\text { Growth rate of real house price indexes, } \\
\text { deflated by CPI. }\end{array}$ & $\begin{array}{l}\text { OECD; and Oxford Economics (Austria, Brazil, } \\
\text { China, Croatia, Czech Republic, Greece, } \\
\text { Hungary, Lithuania, Poland, Slovak Republic). }\end{array}$ \\
\hline Debt service to income ratio & $\begin{array}{l}\text { Ratio of debt service (interest payments } \\
\text { and principal repayment) }\end{array}$ & BIS. Available for 17 economies. \\
\hline
\end{tabular}




\section{Appendix Table 1 - Variable definitions and data sources - continued}

\begin{tabular}{|c|c|c|}
\hline Variable & Definition & Sources \\
\hline Real stock price growth rate & $\begin{array}{l}\text { Growth rate of the MSCI equity index, } \\
\text { except for Israel (Tel Aviv Stock } \\
\text { Exchange General Price Index), Korea } \\
\text { (Index Korea Exchange Composite), } \\
\text { Latvia (OMX Riga), Lithuania (OMX } \\
\text { Vilnius), Luxembourg (Luxembourg } \\
\text { Stock Exchange General), Portugal } \\
\text { (Index PSI-20), and Slovakia } \\
\text { (Slovakia SAX 16), deflated by CPI. }\end{array}$ & $\begin{array}{l}\text { Datastream and OECD National } \\
\text { Accounts Statistics. }\end{array}$ \\
\hline $\begin{array}{l}\text { Cyclically-adjusted government net } \\
\text { lending }\end{array}$ & $\begin{array}{l}\text { Cyclically-adjusted general } \\
\text { government net lending as a } \\
\text { percentage of potential GDP. }\end{array}$ & OECD Economic Outlook database. \\
\hline Macroprudential variables & & iMaPP database. \\
\hline Homeownership rates & $\begin{array}{l}\text { Proportion of the population aged } \\
\text { between } 25 \text { and } 84 \text { owing a house in } \\
\text { total population aged between } 25 \text { and } \\
84 \text {. }\end{array}$ & Luxembourg Income Study. \\
\hline Housing equity withdrawal & $\begin{array}{l}\text { Dummy variable equal to one of } \\
\text { housing equity withdrawal is available } \\
\text { in the country, zero otherwise. }\end{array}$ & $\begin{array}{l}\text { Andrews (2010), Igan and Loungani } \\
\text { (2012). }\end{array}$ \\
\hline Consumer debt & $\begin{array}{l}\text { Debt used for the purchase of } \\
\text { consumption of durable and non- } \\
\text { durable goods divided by household } \\
\text { gross disposable income (annual data). } \\
\text { Consumer credit is in general divided } \\
\text { into open accounts, personal loans at } \\
\text { banks, other personal loans, credit } \\
\text { card facilities, and instalment sale } \\
\text { transactions and lease transactions. }\end{array}$ & $\begin{array}{l}\text { National central banks, except for } \\
\text { Austria, Czech Republic, Germany, } \\
\text { Denmark, Estonia, Finland, Hungary, } \\
\text { Ireland, Luxembourg, Poland, Portugal, } \\
\text { Slovak Republic, Slovenia, Spain, and } \\
\text { Sweden (ECB). }\end{array}$ \\
\hline Housing debt & $\begin{array}{l}\text { Debt used for the purchase of a house } \\
\text { divided by household gross disposable } \\
\text { income (annual data). }\end{array}$ & Idem as for Consumer debt. \\
\hline Pension funds & $\begin{array}{l}\text { Average } 2009-19 \text { of total assets in } \\
\text { retirement savings plans, as a percent } \\
\text { of GDP. }\end{array}$ & $\begin{array}{l}\text { OECD Pension Markets in Focus } 2020 . \\
\text { Table AB3 of } \\
\text { http://www.oecd.org/daf/fin/private- } \\
\text { pensions/Pension-Markets-in-Focus- } \\
\text { 2020-Statistical-Annex.xlsx }\end{array}$ \\
\hline
\end{tabular}

Note: The household sector refers to the aggregate account of households and non-profit institutions serving households (NPISHs). 


\section{Appendix Table 2 - Change in saving rate and positive versus negative changes of debt ratios}

\begin{tabular}{|c|c|c|c|c|c|c|c|c|}
\hline & \multicolumn{8}{|c|}{ Dependent variable: $\Delta$ Household gross saving rate } \\
\hline & (1) & (2) & (3) & (4) & (5) & (6) & (7) & (8) \\
\hline Lagged $\Delta$ Saving rate & $\begin{array}{l}0.007 \\
(0.22)\end{array}$ & $\begin{array}{l}0.007 \\
(0.21)\end{array}$ & $\begin{array}{l}0.021 \\
(0.64)\end{array}$ & $\begin{array}{l}0.024 \\
(0.79)\end{array}$ & $\begin{array}{l}-0.045 \\
(-0.52)\end{array}$ & $\begin{array}{l}-0.001 \\
(-0.01)\end{array}$ & $\begin{array}{l}0.040 \\
(0.53)\end{array}$ & $\begin{array}{l}0.110 \\
(1.12)\end{array}$ \\
\hline$\Delta \log ($ Real disposable income $\mathrm{Yd})$ & $\begin{array}{c}25.068^{* * *} \\
(7.10)\end{array}$ & $\begin{array}{c}24.987^{* * *} \\
(7.16)\end{array}$ & $\begin{array}{c}24.300^{* * *} \\
(7.21)\end{array}$ & $\begin{array}{c}17.942^{* * *} \\
(4.15)\end{array}$ & $\begin{array}{c}28.494^{* * *} \\
(5.91)\end{array}$ & & $\begin{array}{c}38.294^{* * *} \\
(4.05)\end{array}$ & $\begin{array}{c}30.023^{*} \\
(1.74)\end{array}$ \\
\hline$\Delta$ Real growth rate of $Y d$ & $\begin{array}{c}0.131^{* * *} \\
(5.26)\end{array}$ & $\begin{array}{c}0.129^{* * *} \\
(5.35)\end{array}$ & $\begin{array}{c}0.151^{* * *} \\
(5.56)\end{array}$ & $\begin{array}{c}0.152^{* * * *} \\
(5.73)\end{array}$ & $\begin{array}{c}0.122^{* *} \\
(2.10)\end{array}$ & & $\begin{array}{l}0.110 \\
(1.40)\end{array}$ & $\begin{array}{c}0.176^{* *} \\
(1.96)\end{array}$ \\
\hline$\Delta$ Terms of trade ${ }^{(a)}$ & $\begin{array}{l}-6.440 \\
(-1.62)\end{array}$ & $\begin{array}{l}-6.512 \\
(-1.63)\end{array}$ & $\begin{array}{l}-6.674^{*} \\
(-1.76)\end{array}$ & $\begin{array}{l}-5.957^{*} \\
(-1.87)\end{array}$ & $\begin{array}{l}-5.680 \\
(-1.68)\end{array}$ & & $\begin{array}{l}-9.763 \\
(-1.16)\end{array}$ & $\begin{array}{l}-2.114 \\
(-0.29)\end{array}$ \\
\hline$\Delta$ Old dependency ratio & $\begin{array}{l}-0.088 \\
(-0.45)\end{array}$ & $\begin{array}{l}-0.093 \\
(-0.50)\end{array}$ & $\begin{array}{l}-0.003 \\
(-0.02)\end{array}$ & $\begin{array}{l}0.023 \\
(0.12)\end{array}$ & $\begin{array}{l}-0.472 \\
(-1.33)\end{array}$ & & & \\
\hline$\Delta$ Young dependency ratio & $\begin{array}{l}0.102 \\
(0.55)\end{array}$ & $\begin{array}{l}0.103 \\
(0.61)\end{array}$ & $\begin{array}{l}0.130 \\
(0.76)\end{array}$ & $\begin{array}{l}0.157 \\
(0.84)\end{array}$ & $\begin{array}{l}-0.172 \\
(-0.91)\end{array}$ & & & \\
\hline$\Delta$ Unemployment rate & $\begin{array}{c}0.507^{* * *} \\
(5.32)\end{array}$ & $\begin{array}{c}0.500^{* * *} \\
(5.29)\end{array}$ & $\begin{array}{c}0.439^{* * * *} \\
(5.20)\end{array}$ & $\begin{array}{c}0.431^{* * *} \\
(5.03)\end{array}$ & $\begin{array}{c}0.522^{* * *} \\
(5.05)\end{array}$ & & $\begin{array}{c}0.437^{* * *} \\
(3.24)\end{array}$ & $\begin{array}{l}0.566^{*} \\
(1.87)\end{array}$ \\
\hline$\Delta$ Inflation rate ${ }^{(a)}$ & $\begin{array}{c}20.325^{* * *} \\
(3.77)\end{array}$ & $\begin{array}{c}20.589^{* * *} \\
(3.76)\end{array}$ & $\begin{array}{c}18.242^{* * *} \\
(3.24)\end{array}$ & $\begin{array}{c}15.835^{* * *} \\
(2.88)\end{array}$ & $\begin{array}{l}-1.589 \\
(-0.15)\end{array}$ & $\begin{array}{l}14.570 \\
(0.22)\end{array}$ & $\begin{array}{l}-7.904 \\
(-0.29)\end{array}$ & $\begin{array}{l}3.102 \\
(0.09)\end{array}$ \\
\hline$\Delta \mathrm{GDP}$ growth volatility & $\begin{array}{c}0.139^{* * *} \\
(2.72)\end{array}$ & $\begin{array}{c}0.142^{* * *} \\
(2.78)\end{array}$ & $\begin{array}{c}0.137^{* * *} \\
(2.80)\end{array}$ & $\begin{array}{c}0.131^{* *} \\
(2.61)\end{array}$ & $\begin{array}{l}0.046 \\
(0.73)\end{array}$ & & $\begin{array}{l}-0.150 \\
(-0.52)\end{array}$ & \\
\hline$\Delta$ Real interest rate ${ }^{(a)}$ & $\begin{array}{c}19.959^{* * *} \\
(5.47)\end{array}$ & $\begin{array}{c}20.136^{* * *} \\
(5.55)\end{array}$ & $\begin{array}{c}19.889^{* * *} \\
(5.53)\end{array}$ & $\begin{array}{c}19.573^{* * *} \\
(5.49)\end{array}$ & $\begin{array}{c}22.230^{* * *} \\
(4.04)\end{array}$ & & $\begin{array}{l}-1.984 \\
(-0.16)\end{array}$ & $\begin{array}{c}21.186 \\
(1.22)\end{array}$ \\
\hline $\log (\mathrm{Debt} / \mathrm{Yd})$ & $\begin{array}{c}0.371^{* *} \\
(2.47)\end{array}$ & $\begin{array}{c}0.436^{* * *} \\
(2.74)\end{array}$ & $\begin{array}{l}0.381^{* *} \\
(2.28)\end{array}$ & $\begin{array}{l}0.048 \\
(0.26)\end{array}$ & $\begin{array}{l}-0.806 \\
(-1.14)\end{array}$ & & $\begin{array}{l}0.226 \\
(0.43)\end{array}$ & $\begin{array}{l}0.175 \\
(0.12)\end{array}$ \\
\hline$\Delta(\mathrm{Debt} / \mathrm{Yd})$ & $\begin{array}{c}-0.081^{* * *} \\
(-5.06)\end{array}$ & & & & & & & \\
\hline$\Delta($ Debt $/ Y d)>0$ & & $\begin{array}{c}-0.106^{* * *} \\
(-5.36)\end{array}$ & $\begin{array}{c}-0.101^{* * *} \\
(-5.45)\end{array}$ & & $\begin{array}{c}-0.097^{* * *} \\
(-3.44)\end{array}$ & $\begin{array}{l}-0.129 \\
(-0.94)\end{array}$ & $\begin{array}{c}-0.128^{* *} \\
(-2.33)\end{array}$ & $\begin{array}{l}-0.099^{*} \\
(-1.95)\end{array}$ \\
\hline$\Delta($ Debt $/ Y d)<0$ & & $\begin{array}{l}-0.042 \\
(-1.55)\end{array}$ & $\begin{array}{l}-0.040 \\
(-1.57)\end{array}$ & & $\begin{array}{l}-0.031 \\
(-0.99)\end{array}$ & $\begin{array}{l}0.131 \\
(0.47)\end{array}$ & $\begin{array}{l}-0.022 \\
(-0.15)\end{array}$ & $\begin{array}{l}0.003 \\
(0.03)\end{array}$ \\
\hline$\Delta$ Real growth house prices & & & $\begin{array}{c}-0.035^{* * *} \\
(-3.66)\end{array}$ & $\begin{array}{c}-0.032^{* * *} \\
(-3.36)\end{array}$ & $\begin{array}{c}-0.042^{* * *} \\
(-3.32)\end{array}$ & & $\begin{array}{l}-0.067^{*} \\
(-1.86)\end{array}$ & $\begin{array}{l}-0.081 \\
(-1.51)\end{array}$ \\
\hline$\Delta$ Real growth stock prices & & & $\begin{array}{l}0.003 \\
(1.51)\end{array}$ & $\begin{array}{l}0.003 \\
(1.63)\end{array}$ & $\begin{array}{l}0.005 \\
(1.17)\end{array}$ & & $\begin{array}{l}0.010^{* *} \\
(2.17)\end{array}$ & $\begin{array}{l}0.007 \\
(0.89)\end{array}$ \\
\hline Credit effect $(\Delta \mathrm{Debt} / \mathrm{Yd})$ & & & & $\begin{array}{c}-0.068^{* * *} \\
(-5.44)\end{array}$ & & & & \\
\hline Growth effect $(-\Delta Y d / Y d \times D e b t / Y d)$ & & & & $\begin{array}{c}-0.159^{* * *} \\
(-4.19)\end{array}$ & & & & \\
\hline Country fixed effects & Yes & Yes & Yes & Yes & Yes & Yes & Yes & Yes \\
\hline Time fixed effects & Yes & Yes & Yes & Yes & Yes & Yes & No & No \\
\hline R-squared & 0.454 & 0.456 & 0.471 & 0.478 & 0.631 & - & - & - \\
\hline Number of observations & 1,035 & 1,035 & 1,011 & 1,011 & 353 & 938 & 1,035 & 364 \\
\hline Number of countries & 39 & 39 & 39 & 39 & 27 & 39 & 39 & 27 \\
\hline Number of instruments & - & - & - & - & - & 38 & 38 & 26 \\
\hline $\operatorname{AR}(2)$ test $p$-value & - & - & - & - & - & 0.344 & 0.189 & 0.391 \\
\hline Hansen test $p$-value & - & - & - & - & - & 0.315 & 0.109 & 0.250 \\
\hline
\end{tabular}




\section{Appendix Table 3 -Consumption growth and positive versus negative changes of debt ratios}

\begin{tabular}{|c|c|c|c|c|c|c|c|}
\hline & \multicolumn{7}{|c|}{ Dependent variable: Real consumption growth } \\
\hline & \multicolumn{4}{|c|}{$L S D V$} & \multicolumn{3}{|c|}{ System GMM } \\
\hline & (1) & (2) & (3) & (4) & (5) & (6) & (7) \\
\hline Lagged real consumption growth & $\begin{array}{c}0.101^{* * *} \\
(3.21)\end{array}$ & $\begin{array}{c}0.083^{* * *} \\
(2.91)\end{array}$ & $\begin{array}{l}-0.027 \\
(-0.64)\end{array}$ & $\begin{array}{l}0.002 \\
(0.08)\end{array}$ & $\begin{array}{l}0.136 \\
(1.32)\end{array}$ & $\begin{array}{c}0.242^{* * *} \\
(3.08)\end{array}$ & $\begin{array}{l}-0.103 \\
(-0.83)\end{array}$ \\
\hline$\Delta \log ($ Real disposable income $\mathrm{Yd}$ ) & $\begin{array}{c}62.240^{* * * *} \\
(15.36)\end{array}$ & $\begin{array}{c}57.493^{* * *} \\
(13.34)\end{array}$ & $\begin{array}{c}46.426^{* * *} \\
(9.10)\end{array}$ & $\begin{array}{c}48.187^{* * * *} \\
(9.45)\end{array}$ & $\begin{array}{c}77.321^{* * * *} \\
(4.29)\end{array}$ & $\begin{array}{c}56.224^{* * *} \\
(4.89)\end{array}$ & $\begin{array}{c}98.717^{* * *} \\
(4.65)\end{array}$ \\
\hline$\Delta$ Real growth rate of $Y d$ & $\begin{array}{c}-0.091^{* * *} \\
(-3.80)\end{array}$ & $\begin{array}{c}-0.081^{* * *} \\
(-3.54)\end{array}$ & $\begin{array}{l}-0.072^{*} \\
(-2.03)\end{array}$ & $\begin{array}{c}-0.131^{* * *} \\
(-3.02)\end{array}$ & & $\begin{array}{l}-0.057 \\
(-1.26)\end{array}$ & $\begin{array}{l}-0.008 \\
(-0.11)\end{array}$ \\
\hline$\Delta$ Terms of $\operatorname{trade}^{(\mathrm{a})}$ & $\begin{array}{l}6.256 \\
(1.40)\end{array}$ & $\begin{array}{l}5.980 \\
(1.29)\end{array}$ & $\begin{array}{l}6.646 \\
(1.40)\end{array}$ & $\begin{array}{l}-4.656 \\
(-1.57)\end{array}$ & & & $\begin{array}{l}-1.401 \\
(-0.16)\end{array}$ \\
\hline Old dependency ratio & $\begin{array}{l}0.004 \\
(0.15)\end{array}$ & $\begin{array}{l}-0.001 \\
(-0.06)\end{array}$ & $\begin{array}{l}-0.023 \\
(-0.64)\end{array}$ & $\begin{array}{c}-0.106^{* * *} \\
(-3.66)\end{array}$ & & & $\begin{array}{c}-0.133^{* *} \\
(-2.40)\end{array}$ \\
\hline Young dependency ratio & $\begin{array}{l}0.039 \\
(0.91)\end{array}$ & $\begin{array}{l}0.042 \\
(0.89)\end{array}$ & $\begin{array}{l}-0.063^{*} \\
(-1.98)\end{array}$ & $\begin{array}{c}0.248^{* * *} \\
(3.75)\end{array}$ & & & $\begin{array}{l}-0.061^{*} \\
(-1.71)\end{array}$ \\
\hline$\Delta$ Unemployment rate & $\begin{array}{c}-0.594^{* * *} \\
(-5.06)\end{array}$ & $\begin{array}{c}-0.509^{* * *} \\
(-4.47)\end{array}$ & $\begin{array}{c}-0.486^{* * *} \\
(-4.62)\end{array}$ & $\begin{array}{c}-0.525^{* * *} \\
(-5.05)\end{array}$ & & & $\begin{array}{l}0.025 \\
(0.07)\end{array}$ \\
\hline$\Delta$ Inflation rate ${ }^{(a)}$ & $\begin{array}{c}-28.961^{* * *} \\
(-4.21)\end{array}$ & $\begin{array}{c}-27.296^{* * *} \\
(-3.60)\end{array}$ & $\begin{array}{l}-5.302 \\
(-0.53)\end{array}$ & $\begin{array}{c}-48.620^{* *} \\
(-2.66)\end{array}$ & & & $\begin{array}{c}48.508^{*} \\
(1.68)\end{array}$ \\
\hline$\Delta$ GDP growth volatility & $\begin{array}{c}-0.135^{* *} \\
(-2.62)\end{array}$ & $\begin{array}{c}-0.143^{* * *} \\
(-2.86)\end{array}$ & $\begin{array}{c}-0.122^{* *} \\
(-2.48)\end{array}$ & $\begin{array}{c}-0.265^{* *} \\
(-2.80)\end{array}$ & & & \\
\hline$\Delta$ Real interest rate ${ }^{(a)}$ & $\begin{array}{c}-26.659^{* * *} \\
(-6.67)\end{array}$ & $\begin{array}{c}-25.773^{* * *} \\
(-6.27)\end{array}$ & $\begin{array}{c}-25.576^{* * *} \\
(-6.39)\end{array}$ & & & & $\begin{array}{c}43.106^{* *} \\
(2.06)\end{array}$ \\
\hline $\log ($ Debt/Yd $)$ & $\begin{array}{l}-0.515^{*} \\
(-2.00)\end{array}$ & $\begin{array}{l}-0.435 \\
(-1.60)\end{array}$ & $\begin{array}{l}0.468 \\
(0.68)\end{array}$ & & & & $\begin{array}{l}2.268^{*} \\
(1.74)\end{array}$ \\
\hline$\Delta($ Debt $/ Y d)>0$ & $\begin{array}{c}0.124^{* * * *} \\
(5.57)\end{array}$ & $\begin{array}{c}0.096^{* * * *} \\
(4.68)\end{array}$ & $\begin{array}{l}0.033^{*} \\
(1.74)\end{array}$ & $\begin{array}{c}0.104^{* * *} \\
(2.97)\end{array}$ & $\begin{array}{c}0.238^{* *} \\
(2.10)\end{array}$ & $\begin{array}{c}0.455^{* * *} \\
(5.51)\end{array}$ & $\begin{array}{l}-0.064 \\
(-0.55)\end{array}$ \\
\hline$\Delta($ Debt $/ Y d)<0$ & $\begin{array}{l}0.053 \\
(1.55)\end{array}$ & $\begin{array}{l}0.051 \\
(1.52)\end{array}$ & $\begin{array}{l}0.037 \\
(1.51)\end{array}$ & $\begin{array}{l}0.031 \\
(0.89)\end{array}$ & $\begin{array}{l}-0.386 \\
(-0.98)\end{array}$ & $\begin{array}{l}-0.323 \\
(-0.96)\end{array}$ & $\begin{array}{l}0.315 \\
(1.26)\end{array}$ \\
\hline Real growth house prices & & $\begin{array}{c}0.052^{* * * *} \\
(4.17)\end{array}$ & $\begin{array}{c}0.112^{* * *} \\
(6.76)\end{array}$ & $\begin{array}{l}0.041^{*} \\
(1.99)\end{array}$ & & & $\begin{array}{l}0.121^{* *} \\
(2.56)\end{array}$ \\
\hline Real growth stock prices & & $\begin{array}{l}-0.000 \\
(-0.16)\end{array}$ & $\begin{array}{l}0.001 \\
(0.12)\end{array}$ & $\begin{array}{l}0.001 \\
(0.17)\end{array}$ & & & $\begin{array}{l}0.013 \\
(0.71)\end{array}$ \\
\hline Debt service ratio & & & & $\begin{array}{l}-0.031 \\
(-0.54)\end{array}$ & & & \\
\hline Country fixed effects & Yes & Yes & Yes & Yes & Yes & Yes & Yes \\
\hline Time fixed effects & Yes & Yes & Yes & Yes & Yes & No & No \\
\hline R-squared & 0.766 & 0.774 & 0.856 & 0.754 & - & - & - \\
\hline Number of observations & 1,049 & 1,034 & 364 & 340 & 956 & 1,111 & 1,034 \\
\hline Number of countries & 39 & 39 & 27 & 17 & 39 & 39 & 39 \\
\hline Number of instruments & - & - & - & - & 38 & 12 & 30 \\
\hline $\operatorname{AR}(2)$ test $p$-value & - & - & - & - & 0.151 & 0.883 & 0.890 \\
\hline Hansen test $p$-value & - & - & - & - & 0.216 & 0.926 & 0.449 \\
\hline
\end{tabular}




\section{Appendix Table 4 - Change of saving rate and interaction effects of institutional settings with change of debt ratios}

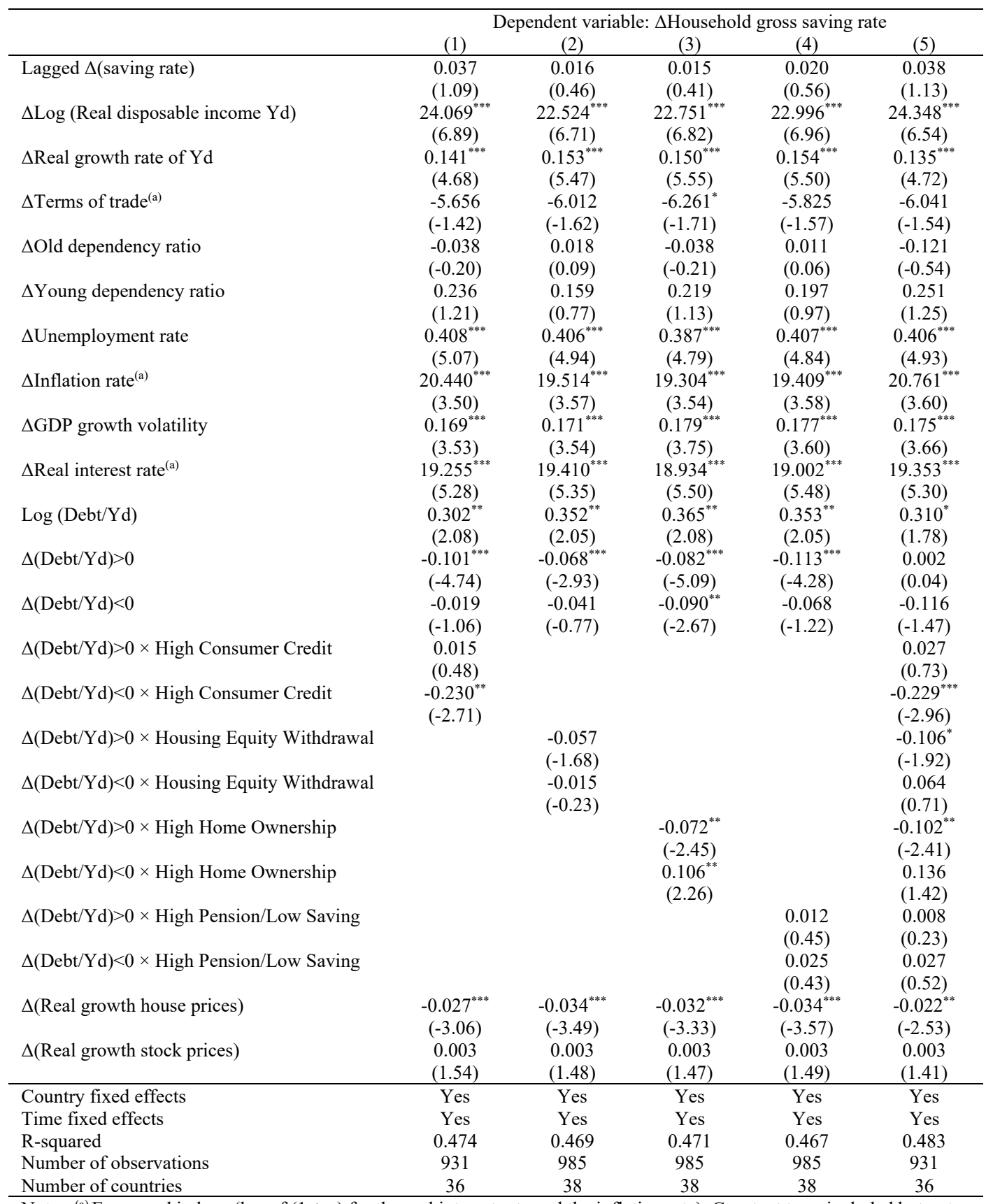

Notes: ${ }^{(a)}$ Expressed in logs $(\log$ of $(1+\mathrm{x})$ for the real interest rate and the inflation rate). Constant term included but not reported. ${ }^{* *},{ }^{* *},{ }^{*}$ denote significativity at the $1 \%, 5 \%$, and $10 \%$ level, respectively. Robust $t$-statistics in parentheses. 


\section{Appendix Table 5 - Consumption growth and interaction effects of institutional settings with change of debt ratios}

\begin{tabular}{|c|c|c|c|c|c|}
\hline & \multicolumn{5}{|c|}{ Dependent variable: Real consumption growth } \\
\hline & (1) & (2) & (3) & (4) & (5) \\
\hline Lagged Real consumption growth & $\begin{array}{l}0.075^{* *} \\
(2.51)\end{array}$ & $\begin{array}{c}0.079^{* * *} \\
(2.77)\end{array}$ & $\begin{array}{c}0.083^{* * *} \\
(2.98)\end{array}$ & $\begin{array}{c}0.081^{* * *} \\
(2.87)\end{array}$ & $\begin{array}{l}0.079^{* *} \\
(2.70)\end{array}$ \\
\hline$\Delta \log ($ Real disposable income $\mathrm{Yd})$ & $\begin{array}{c}59.951^{* * *} \\
(15.61)\end{array}$ & $\begin{array}{c}60.447^{* * *} \\
(14.28)\end{array}$ & $\begin{array}{c}60.090^{* * *} \\
(14.58)\end{array}$ & $\begin{array}{c}59.685^{* * *} \\
(14.56)\end{array}$ & $\begin{array}{c}59.929^{* * *} \\
(15.80)\end{array}$ \\
\hline$\Delta$ Real growth rate of $Y d$ & $\begin{array}{c}-0.087^{* * *} \\
(-3.40)\end{array}$ & $\begin{array}{c}-0.091^{* * *} \\
(-3.89)\end{array}$ & $\begin{array}{c}-0.088^{* * *} \\
(-3.79)\end{array}$ & $\begin{array}{c}-0.090^{* * *} \\
(-3.79)\end{array}$ & $\begin{array}{c}-0.082^{* * *} \\
(-3.43)\end{array}$ \\
\hline$\Delta$ Terms of trade ${ }^{(\mathrm{a})}$ & $\begin{array}{l}5.899 \\
(1.30)\end{array}$ & $\begin{array}{l}5.448 \\
(1.19)\end{array}$ & $\begin{array}{l}5.716 \\
(1.26)\end{array}$ & $\begin{array}{l}5.280 \\
(1.15)\end{array}$ & $\begin{array}{l}6.184 \\
(1.37)\end{array}$ \\
\hline Old dependency ratio & $\begin{array}{l}-0.020 \\
(-0.78)\end{array}$ & $\begin{array}{l}0.002 \\
(0.07)\end{array}$ & $\begin{array}{l}-0.001 \\
(-0.05)\end{array}$ & $\begin{array}{l}0.002 \\
(0.08)\end{array}$ & $\begin{array}{l}-0.017 \\
(-0.64)\end{array}$ \\
\hline Young dependency ratio & $\begin{array}{l}0.038 \\
(0.69)\end{array}$ & $\begin{array}{l}0.034 \\
(0.71)\end{array}$ & $\begin{array}{l}0.041 \\
(0.85)\end{array}$ & $\begin{array}{l}0.039 \\
(0.79)\end{array}$ & $\begin{array}{l}0.036 \\
(0.66)\end{array}$ \\
\hline$\Delta$ Unemployment rate & $\begin{array}{c}-0.478^{* * *} \\
(-4.36)\end{array}$ & $\begin{array}{c}-0.478^{* * *} \\
(-4.33)\end{array}$ & $\begin{array}{c}-0.458^{* * *} \\
(-4.24)\end{array}$ & $\begin{array}{c}-0.476^{* * *} \\
(-4.21)\end{array}$ & $\begin{array}{c}-0.476^{* * *} \\
(-4.34)\end{array}$ \\
\hline$\Delta$ Inflation rate ${ }^{(a)}$ & $\begin{array}{c}-27.971^{* * *} \\
(-3.67)\end{array}$ & $\begin{array}{c}-28.785^{* * *} \\
(-3.81)\end{array}$ & $\begin{array}{c}-28.702^{* * *} \\
(-3.81)\end{array}$ & $\begin{array}{c}-28.642^{* * *} \\
(-3.85)\end{array}$ & $\begin{array}{c}-28.094^{* * *} \\
(-3.63)\end{array}$ \\
\hline$\Delta \mathrm{GDP}$ growth volatility & $\begin{array}{c}-0.171^{* * *} \\
(-3.35)\end{array}$ & $\begin{array}{c}-0.173^{* * *} \\
(-3.26)\end{array}$ & $\begin{array}{c}-0.178^{* * *} \\
(-3.38)\end{array}$ & $\begin{array}{c}-0.179^{* * *} \\
(-3.30)\end{array}$ & $\begin{array}{c}-0.170^{* * *} \\
(-3.36)\end{array}$ \\
\hline$\Delta$ Real interest rate ${ }^{(a)}$ & $\begin{array}{c}-25.419^{* * *} \\
(-6.16)\end{array}$ & $\begin{array}{c}-25.224^{* * *} \\
(-6.04)\end{array}$ & $\begin{array}{c}-24.963^{* * *} \\
(-6.15)\end{array}$ & $\begin{array}{c}-24.912^{* * *} \\
(-6.25)\end{array}$ & $\begin{array}{c}-25.525^{* * *} \\
(-6.02)\end{array}$ \\
\hline $\log ($ Debt/Yd) & $\begin{array}{l}-0.421 \\
(-1.46)\end{array}$ & $\begin{array}{l}-0.422 \\
(-1.53)\end{array}$ & $\begin{array}{l}-0.444 \\
(-1.67)\end{array}$ & $\begin{array}{l}-0.435 \\
(-1.58)\end{array}$ & $\begin{array}{l}-0.420 \\
(-1.40)\end{array}$ \\
\hline$\Delta($ Debt $/ Y d)>0$ & $\begin{array}{c}0.093^{* * *} \\
(5.14)\end{array}$ & $\begin{array}{c}0.061^{* * *} \\
(3.07)\end{array}$ & $\begin{array}{c}0.085^{* * *} \\
(5.46)\end{array}$ & $\begin{array}{c}0.109^{* * * *} \\
(4.08)\end{array}$ & $\begin{array}{l}0.032 \\
(1.01)\end{array}$ \\
\hline$\Delta($ Debt $/ Y d)<0$ & $\begin{array}{l}0.015 \\
(0.62)\end{array}$ & $\begin{array}{l}0.055 \\
(1.09)\end{array}$ & $\begin{array}{l}0.092^{*} \\
(1.81)\end{array}$ & $\begin{array}{l}0.078 \\
(1.16)\end{array}$ & $\begin{array}{l}0.085 \\
(1.34)\end{array}$ \\
\hline$\Delta($ Debt $/ Y d)>0 \times$ High Consumer Credit & $\begin{array}{l}-0.007 \\
(-0.21)\end{array}$ & & & & $\begin{array}{l}-0.024 \\
(-0.55)\end{array}$ \\
\hline$\Delta($ Debt $/ Y d)<0 \times$ High Consumer Credit & $\begin{array}{c}0.303^{* * *} \\
(2.81)\end{array}$ & & & & $\begin{array}{c}0.308^{* * *} \\
(3.24)\end{array}$ \\
\hline$\Delta($ Debt $/ Y d)>0 \times$ Housing Equity Withdrawal & & $\begin{array}{l}0.060^{*} \\
(1.96)\end{array}$ & & & $\begin{array}{l}0.081 \\
(1.46)\end{array}$ \\
\hline$\Delta($ Debt $/ Y d)<0 \times$ Housing Equity Withdrawal & & $\begin{array}{l}0.005 \\
(0.08)\end{array}$ & & & $\begin{array}{l}-0.051 \\
(-0.65)\end{array}$ \\
\hline$\Delta($ Debt $/ Y d)>0 \times$ High Home Ownership & & & $\begin{array}{l}0.051 \\
(1.66)\end{array}$ & & $\begin{array}{l}0.053 \\
(1.29)\end{array}$ \\
\hline$\Delta($ Debt $/ Y d)<0 \times$ High Home Ownership & & & $\begin{array}{l}-0.103 \\
(-1.61)\end{array}$ & & $\begin{array}{l}-0.107 \\
(-1.27)\end{array}$ \\
\hline$\Delta($ Debt $/ Y d)>0 \times$ High Pension/Low Saving & & & & $\begin{array}{l}-0.016 \\
(-0.53)\end{array}$ & $\begin{array}{l}-0.017 \\
(-0.49)\end{array}$ \\
\hline$\Delta($ Debt $/ Y d)<0 \times$ High Pension/Low Saving & & & & $\begin{array}{l}-0.035 \\
(-0.47)\end{array}$ & $\begin{array}{l}-0.014 \\
(-0.21)\end{array}$ \\
\hline Real growth house prices & $\begin{array}{c}0.044^{* * *} \\
(3.14)\end{array}$ & $\begin{array}{c}0.048^{* * *} \\
(3.81)\end{array}$ & $\begin{array}{c}0.048^{* * *} \\
(3.92)\end{array}$ & $\begin{array}{c}0.049^{* * * *} \\
(3.80)\end{array}$ & $\begin{array}{c}0.041^{* * *} \\
(3.20)\end{array}$ \\
\hline Real growth stock prices & $\begin{array}{l}-0.001 \\
(-0.29) \\
\end{array}$ & $\begin{array}{l}-0.001 \\
(-0.20) \\
\end{array}$ & $\begin{array}{l}-0.001 \\
(-0.29) \\
\end{array}$ & $\begin{array}{l}-0.001 \\
(-0.31) \\
\end{array}$ & $\begin{array}{c}-0.000 \\
(-0.09) \\
\end{array}$ \\
\hline Country fixed effects & Yes & Yes & Yes & Yes & Yes \\
\hline Time fixed effects & Yes & Yes & Yes & Yes & Yes \\
\hline R-squared & 0.777 & 0.771 & 0.771 & 0.770 & 0.779 \\
\hline Number of observations & 953 & 1,008 & 1,008 & 1,008 & 953 \\
\hline Number of countries & 36 & 38 & 38 & 38 & 36 \\
\hline
\end{tabular}

Notes: ${ }^{(a)}$ Expressed in logs $(\log$ of $(1+\mathrm{x})$ for the real interest rate and the inflation rate). Constant term included but not reported. $* * * * *, *$ denote significativity at the $1 \%, 5 \%$, and $10 \%$ level, respectively. Robust $t$-statistics in parentheses. 
Appendix Table 6 - Change of saving rate, consumer credit, and mortgages

\begin{tabular}{|c|c|c|c|}
\hline & \multicolumn{3}{|c|}{ Dependent variable: $\Delta$ Household gross saving rate } \\
\hline & \multicolumn{2}{|c|}{$L S D V$} & \multirow{2}{*}{$\frac{\text { System GMM }}{(3)}$} \\
\hline & (1) & (2) & \\
\hline Lagged $\Delta$ (saving rate) & $\begin{array}{l}-0.018 \\
(-0.32)\end{array}$ & $\begin{array}{l}-0.018 \\
(-0.36)\end{array}$ & $\begin{array}{c}0.011 \\
(0.10)\end{array}$ \\
\hline$\Delta \log ($ Real disposable income $\mathrm{Yd})$ & $\begin{array}{c}23.573^{* * *} \\
(3.80)\end{array}$ & $\begin{array}{c}25.219^{* * *} \\
(4.13)\end{array}$ & $\begin{array}{l}1.507 \\
(0.20)\end{array}$ \\
\hline$\Delta$ Real growth rate of $Y d$ & $\begin{array}{l}0.122^{* *} \\
(2.69)\end{array}$ & $\begin{array}{l}0.112^{* *} \\
(2.60)\end{array}$ & $\begin{array}{l}0.041 \\
(0.39)\end{array}$ \\
\hline$\Delta$ Terms of trade ${ }^{(a)}$ & $\begin{array}{l}-8.009^{*} \\
(-1.94)\end{array}$ & $\begin{array}{l}-7.642^{*} \\
(-2.01)\end{array}$ & \\
\hline$\Delta$ Old dependency ratio & $\begin{array}{l}-0.051 \\
(-0.18)\end{array}$ & $\begin{array}{l}-0.012 \\
(-0.04)\end{array}$ & \\
\hline$\Delta$ Young dependency ratio & $\begin{array}{l}0.054 \\
(0.16)\end{array}$ & $\begin{array}{l}0.036 \\
(0.10)\end{array}$ & \\
\hline$\Delta$ Unemployment rate & $\begin{array}{c}0.473^{* * *} \\
(4.12)\end{array}$ & $\begin{array}{c}0.479^{* * *} \\
(3.87)\end{array}$ & \\
\hline$\Delta$ Inflation rate ${ }^{(a)}$ & $\begin{array}{c}15.880^{* *} \\
(2.09)\end{array}$ & $\begin{array}{c}12.807^{*} \\
(1.72)\end{array}$ & \\
\hline$\Delta$ GDP growth volatility & $\begin{array}{l}0.093^{*} \\
(1.84)\end{array}$ & $\begin{array}{l}0.096^{*} \\
(2.00)\end{array}$ & \\
\hline$\Delta$ Real interest rate ${ }^{(a)}$ & $\begin{array}{c}21.272^{* * *} \\
(3.44)\end{array}$ & $\begin{array}{c}21.887^{* * *} \\
(3.39)\end{array}$ & \\
\hline $\log ($ Debt/Yd) & $\begin{array}{l}-0.115 \\
(-0.26)\end{array}$ & $\begin{array}{l}-0.170 \\
(-0.40)\end{array}$ & \\
\hline$\Delta(\mathrm{Debt} / \mathrm{Yd})>0$ & $\begin{array}{c}-0.089^{* * *} \\
(-2.91)\end{array}$ & & \\
\hline$\Delta($ Debt $/ Y d)<0$ & $\begin{array}{l}-0.067^{*} \\
(-1.93)\end{array}$ & & \\
\hline$\Delta($ Consumer debt $/ Y \mathrm{~d})>0$ & & $\begin{array}{l}-0.136 \\
(-1.50)\end{array}$ & $\begin{array}{l}0.066 \\
(0.13)\end{array}$ \\
\hline$\Delta($ Consumer debt $/ Y \mathrm{~d})<0$ & & $\begin{array}{l}-0.209 \\
(-1.23)\end{array}$ & $\begin{array}{l}-0.740 \\
(-1.19)\end{array}$ \\
\hline$\Delta($ Mortgages $/ Y d)>0$ & & $\begin{array}{c}-0.091^{* *} \\
(-2.15)\end{array}$ & $\begin{array}{c}-0.126^{* *} \\
(-2.14)\end{array}$ \\
\hline$\Delta($ Mortgages $/ Y \mathrm{~d})<0$ & & $\begin{array}{l}-0.062 \\
(-1.09)\end{array}$ & $\begin{array}{l}0.156 \\
(1.46)\end{array}$ \\
\hline House prices, real growth & $\begin{array}{l}-0.006 \\
(-0.49)\end{array}$ & $\begin{array}{l}-0.007 \\
(-0.61)\end{array}$ & \\
\hline Stock prices, real growth & $\begin{array}{l}0.005^{*} \\
(1.77)\end{array}$ & $\begin{array}{l}0.004 \\
(1.66)\end{array}$ & \\
\hline Country fixed effects & Yes & Yes & Yes \\
\hline Time fixed effects & Yes & Yes & No \\
\hline R-squared & 0.455 & 0.455 & - \\
\hline Number of observations & 582 & 582 & 615 \\
\hline Number of countries & 36 & 36 & 36 \\
\hline Number of instruments & - & - & 32 \\
\hline $\mathrm{AR}(2)$ test $p$-value & - & - & 0.143 \\
\hline Hansen test $p$-value & - & - & 0.322 \\
\hline
\end{tabular}


Appendix Table 7 - Consumption growth, consumer credit, and mortgages

\begin{tabular}{|c|c|c|c|}
\hline & \multicolumn{3}{|c|}{ Dependent variable: Real consumption growth } \\
\hline & \multicolumn{2}{|c|}{$L S D V$} & \multirow{2}{*}{$\frac{\text { System GMM }}{\text { (3) }}$} \\
\hline & (1) & (2) & \\
\hline Lagged Real consumption growth & $\begin{array}{l}0.099^{*} \\
(1.99)\end{array}$ & $\begin{array}{l}0.094^{*} \\
(1.98)\end{array}$ & $\begin{array}{l}-0.003 \\
(-0.03)\end{array}$ \\
\hline$\Delta \log ($ Real disposable income $\mathrm{Yd}$ ) & $\begin{array}{c}59.677^{* * *} \\
(9.89)\end{array}$ & $\begin{array}{c}57.765^{* * *} \\
(9.92)\end{array}$ & $\begin{array}{c}105.504^{* * *} \\
(4.89)\end{array}$ \\
\hline$\Delta$ Real growth rate of $Y d$ & $\begin{array}{c}-0.092^{* * *} \\
(-2.86)\end{array}$ & $\begin{array}{l}-0.080^{* *} \\
(-2.57)\end{array}$ & $\begin{array}{l}-0.021 \\
(-0.37)\end{array}$ \\
\hline$\Delta$ Terms of trade ${ }^{(a)}$ & $\begin{array}{l}8.919^{* *} \\
(2.09)\end{array}$ & $\begin{array}{l}8.363^{* *} \\
(2.07)\end{array}$ & \\
\hline Old dependency ratio & $\begin{array}{l}-0.020 \\
(-0.43)\end{array}$ & $\begin{array}{l}-0.014 \\
(-0.29)\end{array}$ & \\
\hline Young dependency ratio & $\begin{array}{l}0.006 \\
(0.13)\end{array}$ & $\begin{array}{l}0.001 \\
(0.03)\end{array}$ & \\
\hline$\Delta$ Unemployment rate & $\begin{array}{c}-0.480^{* * *} \\
(-4.89)\end{array}$ & $\begin{array}{c}-0.494^{* * *} \\
(-4.73)\end{array}$ & \\
\hline$\Delta$ Inflation rate ${ }^{(a)}$ & $\begin{array}{c}-25.694^{* * *} \\
(-2.87)\end{array}$ & $\begin{array}{c}-22.625^{* * *} \\
(-2.73)\end{array}$ & \\
\hline$\Delta$ GDP growth volatility & $\begin{array}{l}-0.110^{*} \\
(-2.02)\end{array}$ & $\begin{array}{c}-0.108^{* *} \\
(-2.04)\end{array}$ & \\
\hline$\Delta$ Real interest rate ${ }^{(a)}$ & $\begin{array}{c}-33.550^{* * *} \\
(-4.20)\end{array}$ & $\begin{array}{c}-33.350^{* * *} \\
(-4.21)\end{array}$ & \\
\hline $\log ($ Debt/Yd) & $\begin{array}{l}0.761^{*} \\
(1.72)\end{array}$ & $\begin{array}{l}0.764 \\
(1.68)\end{array}$ & \\
\hline$\Delta($ Debt $/ Y d)>0$ & $\begin{array}{c}0.081^{* * *} \\
(3.64)\end{array}$ & & \\
\hline$\Delta($ Debt $/ Y d)<0$ & $\begin{array}{l}0.039 \\
(1.59)\end{array}$ & & \\
\hline$\Delta($ Consumer debt $/ Y d)>0$ & & $\begin{array}{l}0.258^{* * *} \\
(3.18)\end{array}$ & $\begin{array}{l}0.143 \\
(0.32)\end{array}$ \\
\hline$\Delta($ Consumer debt $/ Y d)<0$ & & $\begin{array}{l}0.072 \\
(0.49)\end{array}$ & $\begin{array}{l}0.545 \\
(0.99)\end{array}$ \\
\hline$\Delta($ Mortgages $/ Y d)>0$ & & $\begin{array}{l}0.065^{*} \\
(1.91)\end{array}$ & $\begin{array}{c}0.148^{* * *} \\
(2.68)\end{array}$ \\
\hline$\Delta($ Mortgages $/ Y d)<0$ & & $\begin{array}{l}0.062 \\
(1.45)\end{array}$ & $\begin{array}{l}-0.172 \\
(-1.56)\end{array}$ \\
\hline House prices, real growth & $\begin{array}{l}0.053^{* * *} \\
(3.28)\end{array}$ & $\begin{array}{c}0.055^{* * *} \\
(3.27)\end{array}$ & \\
\hline Stock prices, real growth & $\begin{array}{l}0.002 \\
(0.47) \\
\end{array}$ & $\begin{array}{l}0.003 \\
(0.55) \\
\end{array}$ & \\
\hline Country fixed effects & Yes & Yes & Yes \\
\hline Time fixed effects & Yes & Yes & No \\
\hline R-squared & 0.821 & 0.823 & - \\
\hline Number of observations & 587 & 587 & 617 \\
\hline Number of countries & 36 & 36 & 36 \\
\hline Number of instruments & - & - & 28 \\
\hline $\mathrm{AR}(2)$ test $p$-value & - & - & 0.356 \\
\hline Hansen test $p$-value & - & - & 0.191 \\
\hline
\end{tabular}




\section{REFERENCES}

Abiad, A., E. Detragiache, and T., Tressel. 2010. "A New Database of Financial Reforms." IMF Economic Review 57, 281-302.

Alam, Z., A. Alter, J. Eiseman, G. Gelos, H. Kang, M. Narita, E. Nier, and N. Wang. 2019. "Digging Deeper - Evidence on the Effects of Macroprudential Policies from a New Database." IMF Working Paper 19/66.

Andrews, D. 2010. "Real House Prices in OECD Countries - The Role of Demand Shocks and Structural and Policy Factors." OECD Economics Department Working Papers, No. 831.

Arena, M., T. Chen, S. Mo Choi, N. Geng, C. Gueye, T. Lybek, E. Papageorgiou, and Y. Zhang. 2020. "Macroprudential Policies and House Prices in Europe." Departmental Paper Series No. 3. European Department. IMF.

Attanasio, O., L. Picci, and A.E. Scorcu. 2000. "Saving, Growth, and Investment: A Macroeconomic Analysis Using a Panel of Countries." The Review of Economics and Statistics Vol. 82, No. 2, 182-211.

Auclert, A., W. Dobbie, and P. Goldsmith-Pinkham. 2019. "Macroeconomic Effects of Debt Relief: Consumer Bankruptcy Protections in the Great Recession." NBER Working Paper No. 25685.

Bacchetta, P. and S. Gerlach. 1997. "Consumption and Credit Constraints: International Evidence.” Journal of Monetary Economics, Vol. 40, No. 2, 207-238.

Bailliu, J., K. Kartashova, and C. Meh. 2012. "Household Borrowing and Spending in Canada." Bank of Canada Review, Winter 2011-2012, 16-29.

Baker, S. 2018. "Debt and the Response to Household Income Shocks: Validation and Application of Linked Financial Account Data", Journal of Political Economy, 126, 1504-1557.

Balta, N. and E. Ruscher. 2011. "Household Savings and Mortgage Decisions: The Role of the "Down-payment Channel" in the Euro Area." Economic Papers 445, European Commission, Directorate-General for Economic and Financial Affairs.

Benito, A., J. Thompson, M. Waldron, and R. Wood. 2006. "House Prices and Consumer Spending." Bank of England Quarterly Bulletin, Summer 2006.

Bhutta, N. 2015. "The Ins and Outs of Mortgage Debt During the Housing Boom and Bust." Journal of Monetary Economics, vol. 76(C), 284-298.

Blundell, R. and S. Bond. 1998. "Initial Conditions and Moment Restrictions in Dynamic Panel Data Models.” Journal of Econometrics, Vol. 87, No. 1, pp. 115-143, August.

Bouis, R., A. K. Christensen, and B. Cournède. 2013. "Deleveraging: Challenges, Progress and Policies.” OECD Economics Department Working Papers, No. 1077. 
Campbell, J. and J. Cocco. 2007. "How Do House Prices Affect Consumption? Evidence from Micro Data." Journal of Monetary Economics, vol. 54, No. 3, 591-621.

Carroll, C. 2001. "A Theory of the Consumption Function, With and Without Liquidity Constraints." Journal of Economic Perspectives Vol. 15, No. 3, 23-45.

Carroll, C., J. Slacalek, and M. Sommer. 2019. "Dissecting Saving Dynamics: Measuring Wealth, Precautionary, and Credit Effects.” NBER Working Paper No. 26131.

Carstensen, K., O. Hülsewig, and T. Wollmershäuser. 2009. "Monetary Policy Transmission and House Prices: European Cross-Country Evidence." CESifo Working Paper Series No. 2750.

Case, K, J. Quigley, and R. Shiller. 2005. "Comparing Wealth Effects: The Stock Market versus the Housing Market." Advances in Macroeconomics, Vol. 5, No. 1, 1-32.

Catte, P., N. Girouard, R. Price, and C. André. 2004. "Housing Markets, Wealth and the Business Cycle.” OECD Economics Department Working Paper, No. 394.

Cecchetti, S., M. Mohanty, and F. Zampolli. 2011. "The Real Effects of Debt.” BIS Working Papers No. 352.

Cerutti E., J. Dagher, and G. Dell' Ariccia. 2017. "Housing Finance and Real-Estate Booms: A Cross-Country Perspective.” Journal of Housing Economics. Vol. 38, December, 1-13.

Chmelar, A. 2013. Household Debt and the European Crisis, ECRI Research Reports.

Congressional Budget Office. 2007. "Housing Wealth and Consumer Spending.” Background paper.

Cooper, D. 2012. "U.S. Household Deleveraging: What Do the Aggregate and HouseholdLevel Data Tell Us?” Federal Reserve Bank of Boston Public Policy Briefs No. 2.

Cooper, D. and K. Dynan. 2016. "Wealth Effects and Macroeconomic Dynamics." Journal of Economic Surveys Vol. 30, No. 1, 34-55.

Cuerpo, C., I. Drumond, J. Lendvai, P. Pontuch, and R. Raciborski. 2013. "Indebtedness, Deleveraging Dynamics and Macroeconomic Adjustment." Economic Papers No. 477, April, Directorate-General for Economic and Financial Affairs, European Commission, Brussels.

Damar, E., Gropp, R. and Mordel, A. 2014. 'Banks' Financial Distress, Lending Supply and Consumption Expenditure.” ECB Working Paper No. 1687.

Dembiermont, C., M. Drehmann, and S. Muksakunratana. 2013. "How Much Does the Private Sector Really Borrow? A New Database for Total Credit to the Private Non-Financial Sector.” BIS Quarterly Review, March, 65-81.

Di Maggio, M., A. Kermani, B. Keys, T. Piskorski, R. Ramcharan, A. Seru, and V. Yao. 2017. "Interest Rate Pass-through: Mortgage Rates, Household Consumption, and Voluntary Deleveraging." American Economic Review, Vol. 107, No. 11, 3550-3588. 
Dombret, A. 2013. "The Debt Crisis and its Consequences for the Real Economy." Speech at the Handelsbatt CFO Congress, Königstien.

Dossche, M., M. Forsells, L. Rossi, and G. Stoevsky. 2018. "Private Consumption and Its Drivers in the Current Economic Expansion." ECB Economic Bulletin, Issue 5/2018.

Dynan, K. 2012. "Is a Household Debt Overhang Holding Back Consumption?.” Brookings Papers on Economic Activity, Spring 2012, 299-344.

Dynan, K. and W. Edelberg. 2013. "The Relationship Between Leverage and Household Spending Behavior: Evidence from the 2007-2009 Survey of Consumer Finances." Federal Reserve Bank of St. Louis Review, September/October, 425-448.

Ebner, A. 2013. "A Micro View on Home Equity Withdrawal and its Determinants: Evidence from Dutch Households.” Journal of Housing Economics, Vol. 22, No. 4, 321-337.

Eggertsson, B. and P. Krugman. 2012. "Debt, Deleveraging, and the Liquidity. Trap: A FisherMinsky-Koo Approach.” Quarterly Journal of Economics, Vol. 127, No. 3, 1469-1513.

Elul, R. 2008. “Collateral, Credit History, and the Financial Decelerator.” Journal of Financial Intermediation, Vol. 17, No. 1, 63-88.

Glick, R. and K. Lansing. 2011. "Consumers and the Economy, Part I: Household Credit and Personal Saving.” FRBSF Economic Letter No. 1, January.

Gropp, R., J. Krainer, and E. Laderman. 2019. "Deleveraging and Consumer Credit Supply in the Wake of the 2008-09 Financial Crisis.” International Journal of Central Banking, vol. 15(3). September. 205-251.

Guerrieri, V. and G., Lorenzoni. 2017. "Credit Crises, Precautionary Savings, and the Liquidity Trap.” The Quarterly Journal of Economics, vol. 132, issue 3, 1427-1467.

Günes, A. and C. Tunc. 2018. "Saving Impact of Mortgage Payments: A Microlevel Study for the U.S. Households." Real Estate Economics Vol. 48. 1-26.

Hall, R. 2011. "The Long Slump.” American Economic Review Vol. 101, No. 2, 431-469.

He, D., E. Yao, and K. Li. 2005. "The Growth of Consumer Credit in Asia." Hong Kong Monetary Authority Quarterly Bulletin, March.

Igan, D. and P. Loungani. 2012. “Global Housing Cycles.” IMF Working Paper No. 217.

IMF. 2008. "The Changing Housing Cycle and the Implications for Monetary Policy." World Economic Outlook, Chapter 3.

Jordà, Ò., M. Kornejew, M. Schularick, and A. Taylor. 2020. "Zombies at Large? Corporate Debt Overhang and the Macroeconomy." Staff Reports 951, Federal Reserve Bank of New York.

Kaplan, G., K. Mitman, G. Violante. 2020. "Non-Durable Consumption and Housing Net Worth in the Great Recession: Evidence from Easily Accessible Data." Journal of Public Economics, Vol. 189, September. 
Knotek, E. and J.C. Braxton. 2012. "What Drives Consumer Debt Dynamics?" Federal Reserve Bank of Kansas City Economic Review, No. 4, pp. 31-54.

Koo, R. 2011. "The World in Balance Sheet Recession: Causes, Cure, and Politics." Real World Economics Review No. 58, pp. 19-37.

Korinek A. and A. Simsek. 2016. "Liquidity Trap and Excessive Leverage." American Economic Review 2016, 106(3), pp. 699-738.

Krugman, P. 2013. "Worthwhile Canadian Comparison.” New York Times Blog, June 15.

Li, W. and S. Patwari. 2012. "The Economics of Household Leveraging and Deleveraging." Federal Reserve Bank of Philadelphia Business Review (Third Quarter).

Loayza, N., K. Schmidt-Hebbel, and L. Servén. 2000. "What Drives Saving across the World?." The Review of Economics and Statistics, Vol. 82, No. 2, pp. 165-181.

Lombardi M., M. Mohanty, and I. Shim. 2017. "The Real Effects of Household Debt in the Short and Long Run.” BIS Working Papers 607, Bank for International Settlements.

McCarthy, Y. and K. McQuinn. 2017. "Deleveraging in a Highly Indebted Property Market: Who does it and are there Implications for Household Consumption?" Review of Income and Wealth. Series 63, Number 1, March.

Menegatti, C. and N. Roubini. 2007. "The Direct Link between Housing and Consumption: Wealth Effect and Home Equity Withdrawal." mimeo.

MGI. 2012. Debt and Deleveraging: Uneven Progress on the Path to Growth, McKinsey Global Institute, January.

Mian, A. and A. Sufi. 2011a. "Consumers and the Economy, Part II: Household Debt and the Weak U.S. Recovery.” Federal Reserve Bank of San Francisco Economic Letter No. 02.

Mian, A. and A. Sufi. 2011b. "House Prices, Home Equity Based Borrowing, and the U.S. Household Leverage Crisis.” American Economic Review 101, 2132-2156.

Mian, A. and A. Sufi. 2014. House of Debt: How they (and you) Caused the Great Recession, and How we can Prevent it from Happening Again, University of Chicago Press.

Mian, A., A. Sufi, and E. Verner. 2017. "Household Debt and Business Cycles Worldwide." Quarterly Journal of Economics, Volume 132, Issue 4, 1755-1817.

Mody, A., F. Ohnsorge, and D. Sandri. 2012. "Precautionary Savings in the Great Recession." IMF Economic Review, Vol. 60, No. 1, 114-138.

Morgan Stanley. 2019. “Australia’s Dangerous Dance with Debt”. Research Report.

Muellbauer, J. 2008. "Housing, Credit and Consumer Expenditure." CEPR Discussion Paper No. 6782.

Nickell, S. 1981. "Biases in Dynamic Models with Fixed Effects." Econometrica, Vol. 49, No. 6, 1417-1426. 
Nickell, S. 2004. "Household Debt, House Prices and Consumption Growth." Speech given at Bloomberg, London, Tuesday 14 September 2004.

Office for National Statistics. 2017. National Accounts at a Glance. October 2017.

OECD 2005. Housing Finance Markets in Transition Economies, Trends and Challenges. OECD. Paris.

Olney, M. 1999. "Avoiding Default: The Role of Credit in the Consumption Collapse of 1930." Quarterly Journal of Economics, Vol. 114, No. 1, 319-335.

Pistaferri, L. 2016. "Why Has Consumption Remained Moderate after the Great Recession?" Unpublished manuscript. Stanford University Department of Economics.

Röhn, O. 2010. "New Evidence on the Private Saving Offset and Ricardian Equivalence." OECD Economics Department Working Papers, No. 762.

Roodman D. 2009. "A Note on the Theme of Too Many Instruments." Oxford Bulletin of Economics and Statistics, Vol. 71, No. 1, 135-158.

Severino, F. and M. Brown. 2020. "Personal Bankruptcy Protection and Household Debt." Unpublished manuscript. Dartmouth College Tuck School of Business and Federal Reserve Bank of New York. December.

Smith, M. 2006. "What Do We Know about Equity Withdrawal by Households in New Zealand?" Reserve Bank of New Zealand workshop Housing, Savings, and the Household Balance Sheet, Wellington, 14 November.

Svensson, L. 2012. "Monetary Policy, Debt and Unemployment." Speech at a meeting at SNS - Centre for Business and Policy Studies, Stockholm, 14 November 2012.

Takáts E. and C. Upper. 2012. "Deleveraging and Recovery." in The ESRB at 1, S. Gerlach, E. Gnan and J. Ulbrich (editors). SUERF, Vienna.

Takáts, E. and C. Upper. 2013. "Credit and Growth after Financial Crises.” BIS Working Papers, No. 416.

Tang, G. and C. Upper. 2010. "Debt Reduction after Crises." BIS Quarterly Review, September, 25-38.

Vidangos, I. 2015. "Deleveraging and Recent Trends in Household Debt." FEDS Notes 201504-06.

Zabai, A. 2017. "Household Debt: Recent Developments and Challenges." BIS Quarterly Review, Bank for International Settlements, December.

Zabai, A. 2020. "How are Household Finances Holding up Against the Covid-19 Shock?"

BIS Bulletin No. 22, Bank for International Settlements, June. 